THE FOUNDATIONS OF THE ORIGIN OF SPECIES, A SKETCH WRITTEN IN 1842 by

\title{
CHARLES DARWIN
}

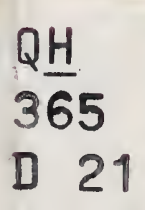





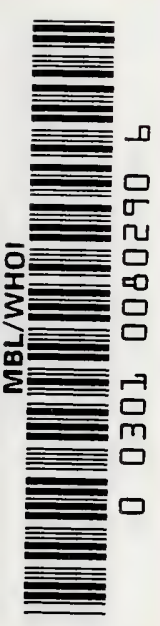







\section{THE FOUNDATIONS OF THE} ORIGIN OF SPECIES 


\section{Cambrioge:}

PRINTED EY JOHN CLAT, M.A. AT THE UNIVERSITY PRESS. 


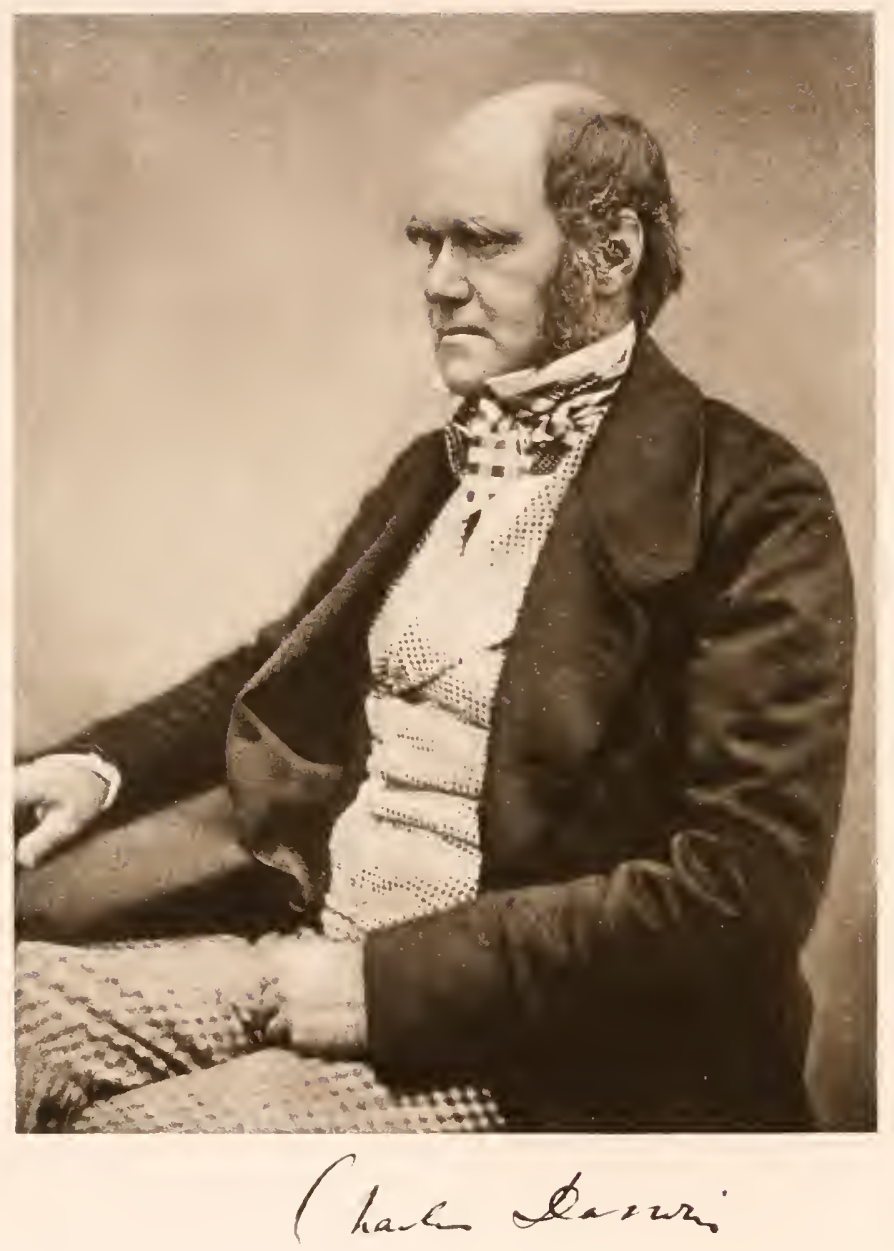




\title{
THE FOUNDATIONS OF THE
} ORIGIN OF SPECIES, A SKETCH WRITTEN IN I 842

\author{
by \\ CHARLES DARWIN
}

Edited by his son

FRANCIS DARWIN

Honorary Fellow of Christ's College

Cambridge :

Printed at the University Press

1909 
Astronomers might formerly have said that God ordered each planet to move in its particular destiny. In same manner God orders each animal created with certain form in certain country. But how much more simple and sublime power,-let attraction act according to certain law, such are inevitable consequences, - let animal $\langle s\rangle$ be created, then by the fixed laws of generation, such will be their successors.

From Darwin's Note Book, 1837, p. 101. 


\section{PRESENTED BY THE SYNDICS}

OF THE UNIVERSITY PRESS TO

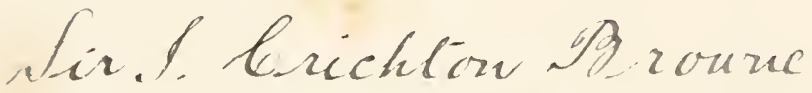

ON THE OCCASION OF THE CELEBRATION AT CAMBRIDGE OF THE CENTENARY OF THE BIRTH OF CHARLES DARWIN AND OF THE FIFTIETH ANNIVERSARY OF THE PUBLICATION OF THE ORIGIN OF SPECIES

\section{CAmbridge,}

23 Fune, 1909. 



\title{
CON'TEN'TS
}

\author{
PART I.
}

pages

$\S$ i. On variation under domestieation, and on the principles

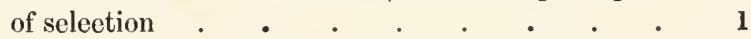

$\S$ ii. On variation in a state of nature and on the natural means of selection . . . . . . . . 4

$\$$ iii. On variation in instincts and other mental attributes . 17

\section{PART II.}

$\S \S$ iv. and v. On the evidenee from Geology. (The reasons for eombining the two seetions are given in the Introduetion) . . . . . . . . . . 22

$\$$ vi. Geographieal distribution . . . . . . . 29

$\S$ vii. Affinities and elassification . . . . . . . 35

$\S$ viii. Unity of type in the great elasses . . . . . 38

$\S$ ix. Abortive organs . . . . . . . . . 45

$\S \mathrm{x}$. Reeapitulation and eonclusion . . . . . . 48

Portrait . . . . . . . frontispiece

Faesimile . . . . . . . . to face p. 50

D. 


\section{EXPLANATION OF SIGNS, \&c.}

[ ] Means that the words so enclosed are erased in the original Ms.

\langle\rangle Indicates an insertion by the Editor.

Origin, Ed. vi. refers to the Popular Edition. 


\section{INTRODUCTION}

WE know from the contents of Charles Darwin's Note Book of 1837 that he was at that time a convinced Evolutionist ${ }^{1}$. Nor can there be any doubt that, when he started on board the Beagle, such opinions as he had were on the side of immutability. When therefore did the current of his thoughts begin to set in the direction of Evolution?

We have first to consider the factors that made for such a change. On his departure in 1831, Henslow gave him vol. I. of Lyell's Principles, then just published, with the warning that he was not to believe what he read'. But believe he did, and it is certain (as Huxley has forcibly pointed out ${ }^{3}$ ) that the doctrine of uniformitarianism when applied to Biology leads of necessity to Evolution. If the extermination of a species is no more catastrophic than the natural death of an individual, why should the birth of a species be any more miraculous than the birth of an individual? It is quite clear that this thought was vividly present to Darwin when he was writing out his early thoughts in the 1837 Note Book ${ }^{4}:-$

"Propagation explains why modern animals same type as extinct, which is law almost proved.

1 See the extracts in Life and Letters of Charles Darwin, ii. p. 5. 2 The second volume,-especially important in regard to Evolution,--
reached him in the autumn of 1832 , as Prof. Judd has pointed out in his most interesting paper in Darwin and Modern Science. Cambridge, 1909.

${ }^{3}$ Obituary Notice of C. Darwin, Proc. $R$. Soc. vol. 44. Reprinted in Huxley's Collected Essays. See also Life and Letters of C. Jarwin, ii. p. 179 .

${ }_{4}^{4}$ See the extracts in the Life and Letters, ii. p. 5 , 
They die, without they change, like golden pippins; it is a generation of species like generation of individuals."

"If species generate other species their race is not utterly cut off."

These quotations show that he was struggling to see in the origin of species a process just as scientifically comprehensible as the birth of individuals. They show, I think, that he recognised the two things not merely as similar but as identical.

It is impossible to know how soon the ferment of uniformitarianism began to work, but it is fair to suspect that in 1832 he had already begun to see that mutability was the logical conclusion of Lyell's doctrine, though this was not acknowledged by Lyell himself.

There were however other factors of change. In his Autobiography ${ }^{1}$ he wrote:- "During the voyage of the Beagle I had been deeply impressed by discovering in the Pampean formation great fossil animals covered with armour like that on the existing armadillos; secondly, by the manner in which closely allied animals replace one another in proceeding southward over the Continent; and thirdly, by the South American character of most of the productions of the Galapagos archipelago, and more especially by the manner in which they differ slightly on each island of the group; none of the islands appearing to be very ancient in a geological sense. It was evident that such facts as these, as well as many others, could only be explained on the supposition that species gradually become modified; and the subject haunted me."

Again we have to ask: how soon did any of these influences produce an effect on Darwin's mind? Different answers have been attempted. Huxley $^{2}$ held that these facts could not have produced their essential effect until the voyage had

1 Life and Letters, i. p. 82.

${ }^{2}$ Obituary Notice, loc. cit. 
come to an end, and the "relations of the existing" with the extinct species and of the species of the different geographical areas with one another were determined with some exactness." He does not therefore allow that any appreciable advance towards evolution was made during the actual voyage of the Beagle.

Professor Judd ${ }^{1}$ takes a very different view. He holds that November 1832 may be given with some confidence as the "date at which Darwin commenced that long series of observations and reasonings which eventually culminated in the preparation of the Origin of Species."

Though I think these words suggest a more direct and continuous march than really existed between fossil-collecting in 1832 and writing the Origin of Species in 1859, yet I hold that it was during the voyage that Darwin's mind began to be turned in the direction of Evolution, and I am therefore in essential agreement with Prof. Judd, although I lay more stress than he does on the latter part of the voyage.

Let us for a moment confine our attention to the passage, above quoted, from the Autobiography and to what is said in the Introduction to the Origin, Ed. i., viz. "When on board H.M.S. 'Beagle,' as naturalist, I was much struck with certain facts in the distribution of the inhabitants of South America, and in the geological relations of the present to the past inhabitants of that continent." These words, occurring where they do, can only mean one thing,- - namely that the facts suggested an evolutionary interpretation. And this being so it must be true that his thoughts began to flow in the direction of Descent at this early date.

I am inclined to think that the "new light which was rising in his mind ${ }^{2}$ " had not yet attained any

1 Darwin and Modern Science.
2 Huxley, Obituary, p. xi. 
effective degree of steadiness or brightness. I think so because in his Pocket Book under the date 1837 he wrote, "In July opened first note-book on 'transmutation of species.' Had been greatly struck firom about month of previous March ${ }^{1}$ on character of South American fossils, and species on Galapagos Archipelago. 'These facts origin (especially latter), of all my views." But he did not visit the Galapagos till 1835 and I therefore find it hard to beliere that his evolutionary views attained any strength or permanence until at any rate quite late in the voyage. The Galapagos facts are strongly against Huxley's view, for Darwin's attention was "thoroughly aroused" ${ }^{2}$ by comparing the birds shot by himself and by others on board. The case must have struck him at once,- - without waiting for accurate determinations, - as a microcosm of evolution.

It is also to be noted, in regard to the remains of extinct animals, that, in the above quotation from his Pocket Book, he speaks of March 1837 as the time at which he began to be "greatly struck on character of South American fossils," which suggests at least that the impression made in 1832 required reinforcement before a really powerful effect was produced.

We may therefore conclude, I think, that the evolutionary current in my father's thoughts had continued to increase in force from 1832 onwards, being especially reinforced at the Galapagos in 1835 and again in 1837 when he was overhauling the results, mental and material, of his travels. And that when the above record in the Pocket Book was made he unconsciously minimised the earlier beginnings of his theorisings, and laid more stress on the recent thoughts which were

1 In this citation the italics are mine.

2 Journal of Researches, Ed. 1860, p. 394. 
naturally more vivid to him. In his letter ${ }^{2}$ to Otto Zacharias (1877) he wrote, "On my return home in the autumn of 1836 , I immediately began to prepare my Journal for publication, and then saw how many, facts indicated the common descent of species." This again is evidence in favour of the view that the later growths of his theory were the essentially important parts of its development.

In the same letter to Zacharias he says, "When I was on board the Beagle I believed in the permanence of species, but as far as I can remember vague doubts occasionally flitted across my mind." Unless Prof. Judd and I are altogether wrong in believing that late or early in the voyage (it matters little which) a definite approach was made to the evolutionary standpoint, we must suppose that in 40 years such advance had shrunk in his recollection to the dimensions of "vague doubts." The letter to Zacharias shows I think some forgetting of the past where the author says, "But I did not become convinced that species were mutable until, I think, two or three years had elapsed." It is impossible to reconcile this with the contents of the evolutionary Note Book of 1837. I have no doubt that in his retrospect he felt that he had not been "convinced that species were mutable" until he had gained a clear conception of the mechanism of natural selection, i.e. in 1838-9.

But even on this last date there is some room, not for doubt, but for surprise. 'The passage in the Autobiography ${ }^{2}$ is quite clear, namely that in October 1838 he read Malthus's Essay on the principle of Population and "being well prepared to appreciate the struggle for existence..., it at once struck me that under these circumstances favourable variations would tend to be preserved,

1 F. Darwin's Life of Charles Darwin (in one volume), 1892, p. 166.

${ }^{2}$ Life and Letters, i. p. 83. 
and unfavourable ones to be destroyed. The result of this would be the formation of new species. Here then I had at last got a theory by which to work."

It is surprising that Malthus should have been needed to give him the clue, when in the Note Book of 1837 there should occur-however obscurely expressed - the following forecast ${ }^{1}$ of the importance of the survival of the fittest. "With respect to extinction, we can easily see that a variety of the ostrich $\left(\right.$ Petise $\left.^{2}\right)$, may not be well adapted, and thus perish out; or on the other hand, like Orpheus ${ }^{3}$, being favourable, many might be produced. This requires the principle that the permanent variations produced by confined breeding and changing circumstances are continued and produce(d) according to the adaptation of such circumstances, and therefore that death of species is a consequence (contrary to what would appear in America) of non-adaptation of circumstances."

I can hardly doubt, that with his knowledge of the interdependence of organisms and the tyranny of conditions, his experience would have crystallized out into "a theory by which to work" even without the aid of Malthus.

In my father's Autobiography" he writes, "In June 1842 I first allowed myself the satisfaction of writing a very brief abstract of my theory in pencil in 35 pages; and this was enlarged during the summer of 1844 into one of 230 pages $^{5}$, which I had fairly copied out and still possess." It is the first of these Essays, - the one in 35 pages,-which is now printed under the title The Foundations of the Origin of Species.

1 Life and Letters, ii. p. 8.

2 Avestruz Petise, i.e. Rhea Darwini.

3 A bird.

4 Life and Letters, i. 1. 84.

5 It contains as a fact $231 \mathrm{pp}$. It is a strongly bound folio, interleaved with blank pages, as though for notes and additions. His own Ms. from which it was copied contains $189 \mathrm{pp}$. 
It will be noted that in the above passage he does not mention the ms. of the Foundations as being in existence, and when I was at work on Life and Letters I had not seen it. It only came to light after my mother's death in 1896 when the house at Down was vacated. The us. was hidden in a cupboard under the stairs which was not used for papers of any value, but rather as an overflow for matter which he did not wish to destroy.

The statement in the Autobiography that the ms. was written in 1842 agrees with an entry in my father's Diary :-

"1842. May 18th went to Maer. June 15th to Shrewsbury, and on 18th to Capel Curig....During my stay at Maer and Shrewsbury (five years after conmencement) wrote pencil sketch of my species theory." Again in a letter to Lyell (June 18, 1858) he speaks of his " MS. sketch written out in $1842^{1}$." In the Origin of Species, Ed. i. p. 1, he speaks of beginning his speculations in 1837 and of allowing himself to draw up some "short notes" after "five year's' work," i.e. in 1842. So far there seems no doubt as to 1842 being the date of the Foundations; but there is evidence in favour of an earlier date? Thus across the Table of Contents of the bound copy of the 1844 NS. is written in my father's hand "This was sketched in 1839." Again in a letter to Mr Wallace ${ }^{3}$ (Jan. 25, 1859) he speaks of his own contributions to the Linnean paper ${ }^{\star}$ of July 1,1858 , as "written in 1839, now just twenty years ago." This statement as it stands is undoubtedly incorrect, since the extracts are from the ms. of 1844 , about the date of which no doubt exists; but even if it could be supposed to refer to the Foundations, it must, I think, be rejected. I can only account for his mistake by the supposition that my father had in

1 Life and Letters, ii. p. 116.

3 Life and Letters, ii. p. 146.
2 Life and Letters, ii. p. 10.

4 J. Linn. Soc. Zool. ii. p. 45. 
mind the date (1839) at which the framework of his theory was laid down. It is worth noting that in his Autobiography (p. 88) he speaks of the time "about 1839 , when the theory was clearly conceived." However this may be there can be no doubt that 1842 is the correct date. Since the publication of Life and Letters I have gained fresh evidence on this head. A small packet containing $13 \mathrm{pp}$. of MS. came to light in 1896. On the outside is written "First Pencil Sketch of Species Theory. Written at Maer and Shrewsbury during May and June 1842." It is not however written in pencil, and it consists of a single chapter on The Principles of Variation in Domestic Organisms. A single unnumbered page is written in pencil, and is headed "Maer, May 1842, useless"; it also bears the words "This page was thought of as introduction." It consists of the briefest sketch of the geological evidence for evolution, together with words intended as headings for discussion,- - such as "Affinity,-_unity of type,fotal state,-abortive organs."

The back of this "useless" page is of some interest, although it does not bear on the question of date,- the matter immediately before us.

It seems to be an outline of the Foundations, consisting of the titles of the three chapters of which it was to have consisted. isms.

"I. The Principles of Var. in domestic organ-

"II. The possible and probable application of these same principles to wild animals and consequently the possible and probable production of wild races, analogous to the domestic ones of plants and animals.

"III. The reasons for and against believing that such races have really been produced, forming what are called species."

It will be seen that Chapter III as originally 
designed corresponds to Part II (p. 22) of the Foundations, which is (p. 7) defined by the author as discussing "whether the characters and relations of animated things are such as favour the idea of wild species being races descended from a common stock." Again at p. 23 the author asks "What then is the evidence in favour of it (the theory of descent) and what the evidence against it." The generalised section of his Essay having been originally Chapter $\mathrm{III}^{1}$ accounts for the curious error which occurs in pp. 18 and 22 where the second Part of the Foundations is called Part III.

The division of the Essay into two parts is maintained in the enlarged Essay of 1844 in which he writes:- "The Second Part of this work is devoted to the general consideration of how far the general economy of nature justifies or opposes the belief that related species and genera are descended from common stocks." The Origin of Species however is not so divided.

We may now return to the question of the date of the Foundations. I have found additional evidence in favour of 1842 in a sentence written on the back of the 'Table of Contents of the 1844 ms.-not the copied version but the original in my father's writing:- "This was written and enlarged from a sketch in 37 pages $^{2}$ in Pencil (the latter written in summer of 1842 at Maer and Shrewsbury) in beginning of 1844, and finished it $\langle$ sic $\rangle$ in July; and finally corrected the copy by $\mathrm{Mr}$ Fletcher in the last week in September." On the whole it is impossible to doubt that 1842 is the date of the Foundations.

1 It is evident that Parts and Chapters were to some extent interehangeable in the author's mind, for p. 1 (of the Ms. we have been diseussing) is headed in ink Chapter I, and afterwards altered in peneil to Part 1 .

2 On p. 23 of the us. of the Foundations is a referenee to the "baek of p. 21 bis": this suggests that additional pages had been interpolated in the ms. and that it may onee have had 37 in place of $35 \mathrm{pp}$. 
The sketch is written on bad paper with a soft pencil, and is in many parts extremely difficult to read, many of the words ending in mere scrawls and being illegible without context. It is evidently written rapidly, and is in his most elliptical style, the articles being fiequently omitted, and the sentences being loosely composed and often illogical in structure. There is much erasure and correction, apparently made at the moment of writing, and the MS. does not give the impression of having been re-read with any care. The whole is more like hasty memoranda of what was clear to himself, than material for the convincing of others.

Many of the pages are covered with writing on the back, an instance of his parsimony in the matter of paper ${ }^{1}$. This matter consists partly of passages marked for insertion in the text, and these can generally (though by no means always) be placed where he intended. But he also used the back of one page for a preliminary sketch to be rewritten on a clean sheet. These parts of the work have been printed as footnotes, so as to allow what was written on the front of the pages to form a continuous text. A certain amount of repetition is unavoidable, but much of what is written on the backs of the pages is of too much interest to be omitted. Some of the matter here given in footnotes may, moreover, have been intended as the final text and not as the preliminary sketch.

When a word cannot be deciphered, it is replaced by:-〈illegible〉, the angular brackets being, as already explained, a symbol for an insertion by the editor. More commonly, however, the context makes the interpretation of a word reasonably sure although the word is not strictly legible. Such words are followed by an inserted mark of interrogation 〈? . 
Lastly, words inserted by the editor, of which the appropriateness is doubtful, are printed thus 〈variation?).

Two kinds of erasure occur in the MS. One by vertical lines which seem to have been made when the $35 \mathrm{pp}$. Ms. was being expanded into that of 1844, and merely imply that such a page is done with: and secondly the ordinary erasures by horizontal lines. I have not been quite consistent in regard to these: I began with the intention of printing (in square brackets) all such erasures. But I ultimately found that the confusion introduced into the already obscure sentences was greater than any possible gain; and many such erasures are altogether omitted. In the same way I have occasionally omitted hopelessly obscure and incomprehensible fragments, which if printed would only have burthened the text with a string of (illegible)s and queried words. Nor have I printed the whole of what is written on the backs of the pages, where it seemed to me that nothing but unnecessary repetition would have been the result.

In the matter of punctuation I have given myself a free hand. I may no doubt have misinterpreted the author's meaning in so doing, but without such punctuation the number of repellantly crabbed sentences would have been even greater than at present.

The sections into which the Essay is divided are in the original merely indicated by a gap in the MS. or by a line drawn across the page. No titles are given except in the case of $\S$ vIII., and $\S$ II. is the only section which has a number in the original. I might equally well have made sections of what are now subsections, e.g. Natural Selection p. 7, or Extermination p. 28. But since the present sketch is the germ of the Essay of 1844, it seemed best to preserve the identity between the two works, by using such of 
the author's divisions as correspond to the chapters of the enlarged version of 1844. The geological discussion with which Part II begins corresponds to two chapters (IV and V) of the 1844 Essay. I have therefore described it as $\$$ IV. and v., although I cannot make sure of its having originally consisted of two sections. With this exception the ten sections of the Foundations correspond to the ten chapters of the MIS. of 1844 .

The Origin of Species differs from the Foundations in not being divided into two parts. But the two volumes resemble each other in general structure. Both begin with a statement of what may be called the mechanism of evolution,- - variation and selection: in both the argument proceeds from the study of domestic organisms to that of animals and plants in a state of nature. This is followed in both by a discussion of the Difficulties on Theory and this by a section Instinct which in both cases is treated as a special case of difficulty. If I had to divide the Origin (first edition) into two parts without any knowledge of earlier MS., I should, I think, make Part II begin with Ch. VI, Difficulties on Theory. A possible reason why this part of the argument is given in Part $I$ of the Foundations may be found in the Essay of 1844, where it is clear that the chapter on instinct is placed in Part I because the author thought it of importance to show that heredity and variation occur in mental attributes. The whole question is perhaps an instance of the sort of difficulty which made the author give up the division of his argument into two Parts when he wrote the Origin. As matters stand $\$ I$. and v. of the Foundations corresponds to the geological chapters, IX and X, in the Origin. From this point onwards the material is grouped in the same order in both works:-geographical distribution; affinities and classification; unity of type 
and morphology; abortive or rudimentary organs; recapitulation and conclusion.

The fact that 17 year's before the publication of the Origin my father should have been able to write out so full an outline of his future work, is very remarkable. In his Autobiography ${ }^{1}$ he writes of the 1844 Essay, "But at that time I overlooked one problem of great importance.... This problem is the tendency in organic beings descended from the same stock to diverge in character as they become modified." The absence of the principle of divergence is of course also a characteristic of the Foundations. But at p. 37, the author is not far from this point of view. The passage referred to is: "If any species, $A$, in changing gets an advantage and that advantage...is inherited, $A$ will be the progenitor of several genera or even families in the hard struggle of nature. $A$ will go on beating out other forms, it might come that $\boldsymbol{A}$ would people 〈the) earth,-we may now not have one descendant on our globe of the one or several original creations." But if the descendants of $A$ have peopled the earth by beating out other forms, they must have diverged in occupying the innumerable diverse modes of life from which they expelled their predecessors. What I wrote ${ }^{2}$ on this subject in 1887 is I think true:- "Descent with modification implies divergence, and we become so habituated to a belief in descent, and therefore in divergence, that we do not notice the absence of proof that divergence is in itself an advantage."

I have called attention in footnotes to many minor points in which the Origin agrees with the Foundations. One of the most interesting is the final sentence on p. 52, which is almost identical with the concluding words of the Origin. I have else- 
where pointed out ${ }^{1}$ that the ancestry of this eloquent passage may be traced one stage further back,-to the Note Book of 1837. I have given this sentence as an appropriate motto for the Foundations in its character of a study of general laws. It will be remembered that a corresponding motto from Whewell's Bridgewater Treatise is printed opposite the title-page of the Origin of Species.

Among other interesting points may be mentioned the "good effects of crossing " being "possibly analogous to good effects of change in condition,"a principle which he upheld on experimental grounds in his Cross and Self-Fertilisation in 1876. We find him also (p.2) recognising the importance of germinal variation, where he speaks of external conditions acting indirectly through the "reproductive functions." He seems to have had constantly in mind the need of referring each variation to a cause, a point of view to which he returned at the close of his life. This subject, though by no means wanting in the Origin, is there overshadowed by considerations which then seemed to him more pressing.

In conclusion, I desire to express my thanks to Mr Wallace for a footnote he was good enough to supply: and to Professor Judd and Professor Bateson for suggestions of value. I am also indebted to $\mathbf{M r}$ Rutherford, of the University Library, for his careful copy of the manuscript.

1 Life and Letters, ii. p. 9.

CAMbridge, April 16, 1909. 
PART I.

\section{$\S$ I. 〈ON Variation under Donestication, and on the Principles of Selection.)}

As individual organism placed under new conditions [often] sometimes varies in a small degree and in very trifling respects such as stature, fatness, sometimes colour, health, habits in animals and probably disposition. Also habits of life develope certain parts. Disuse atrophies. [Most of these slight variations tend to become hereditary.]

When the individual is multiplied for long periods by buds the variation is yet small, though greater and occasionally a single bud or individual departs widely from its type (example) ${ }^{1}$ and continues steadily to propagate, by buds, such new kind.

When the organism is bred for several generations under new or varying conditions, the variation is greater in amount and endless in kind [especially ${ }^{2}$ holds good when individuals have long been exposed to new conditions]. The nature of the external conditions tends to effect some definite change in all or greater part of offspring,--little food, small sizecertain foods harmless \&c. \&c. organs affected and diseases-extent unknown. A certain degree of

1 Evidently a menorandum that an example slould be given.

2 The importance of exposure to new conditions for several generations is insisted on in the Origin, Ed. i. p. 7, also p. 131. In the latter passage the author guards himself against the assumption that variations are "due to chance," and speaks of "our ignorance of the cause of each particular variation." These statements are not always remembered by his critics. 
variation (Müller's twins) ${ }^{1}$ seems inevitable effect of process of reproduction. But more important is that simple $\langle ?\rangle$ generation, especially under new conditions [when no crossing] (causes) infinite variation and not direct effect of external conditions, but only in as much as it affects the reproductive functions ${ }^{2}$. There seems to be no part (beau ideal of liver $)^{3}$ of body, internal or external, or mind or habits, or instincts which does not vary in some small degree and [often] some $\langle ?\rangle$ to a great amount. [All such] variations [being congenital] or those very slowly acquired of all kinds [decidedly evince a tendency to become hereditary], when not so become simple variety, when it does a race. Each parent transmits itspeculiarities, therefore if varieties allowed freely to cross, except by the chance of two characterized by same peculiarity happening to marry, such varieties will be constantly demolished ${ }^{5}$. All bisexual animals must cross, hermaphrodite plants do cross, it seems very possible that her-

1 Cf. Origin, Ed. i. p. 10, vi. p. 9, "Young of the same litter, sometimes differ considerably from each other, though both the young and the parents, as Müller has remarked, have apparently been exposed to exactly the same conditions of life."

${ }_{2}$ This is paralleled by the conclusion in the Origin, Ed.i. p. 8, that "the most frequent cause of variability may be attributed to the male and female reproductive elements having been affected prior to the act of conception."

3 The meaning seems to be that there must be some variability in the liver otherwise anatomists would not speak of the 'beau ideal' of that organ.

4 The position of the following passage is uncertain. "If individuals of two widely different varieties be allowed to cross, a third race will be formed - a most fertile source of the variation in domesticated animals. 〈In the Origin, Ed. i. p. 20 the author says that "the possibility of making distinct races by crossing has been greatly exaggerated." $>$ If freely allowed, the characters of purc parents will be lost, number of

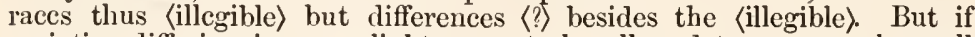
varieties differing in very slight respects be allowed to cross, such small variation will be destroyed, at least to our senses, - a variation [clearly] just to be distinguished by long legs will have offspring not to be so distinguished. Free crossing great agent in producing uniformity in any breed. Introduce tendency to revert to parent form."

5 The swamping effect of intercrossing is referred to in the Origin, Ed. i. p. 103 , vi. p. 126. 
maphrodite animals do cross,--conclusion strengthened: ill effects of breeding in and in, good effects of crossing possibly analogous to good effects of change in condition (?) $\rangle^{1}$.

Therefore if in any country or district all animals of one species be allowed freely to cross, any small tendency in them to vary will be constantly counteracted. Secondly reversion to parent form-analogue of vis medicatrix ${ }^{2}$. But if man selects, then new races rapidly formed, - of late years systematically followed,-in most ancient times often practically followed ${ }^{3}$. By such selection make race-horse, dray-horse-one cow good for tallow, another for eating \&c.-one plant's good lay (illegible) in leaves another in fruit \&c. \&c.: the same plant to supply his wants at different times of year. By former means animals become adapted, as a direct effect to a cause, to external conditions, as size of body to amount of food. By this latter means they may also be so adapted, but further they may be adapted to ends and pursuits, which by no possibility can affect growth, as existence of tallow-chandler cannot tend to make fat. In such selected races, if not removed to new conditions, and (if) preserved from all cross, after several generations become very true, like each other and not varying. But man ${ }^{4}$ selects only $\langle ?\rangle$ what is useful and curioushas bad judgment, is capricious,-grudges to destroy those that do not come up to his pattern,--has no

1 A discussion on the intercrossing of hermaplurodites in relation to Knight's views occurs in the Origin, Ed. i. p. 96, vi. p. 119. The parallelism between crossing and changed conditions is briefly given in the Origin, Ed. i. p. 267, vi. p. 391, and was finally investigated in The Effects of Cross and Self-Fertilisation in the Vegetable Kingdom, 1876.

2 There is an article on the vis medicatrix in Brougham's Dissertations, 1839 , a copy of which is in the anthor's library.

3 This is the classification of selection into methodical and unconscions given in the Origin, Ed. i. p. 33, vi. p. 38.

* This passage, and a similar discussion on the power of the Creator (p. 6), correspond to the comparison between the selective capacities of man and nature, in the Origin, Ed. i. p. 83, vi. p. 102. 
[knowledge] power of selecting according to internal variations, - can hardly keep his conditions uniform,-[cannot] does not select those best adapted to the conditions under which 〈the form 〈? lives, but those most useful to him. This might all be otherwise.

\section{$\S$ II. 〈On Variation in a State of Nature and on the Natural Means of Selection.)}

Let us see how far above principles of variation apply to wild animals. Wild animals vary exceedingly little-yet they are known as individuals ${ }^{1}$. British Plants, in many genera number quite uncertain of varieties and species : in shells chiefly external conditions ${ }^{2}$. Primrose and cowslip. Wild animals from different [countries can be recognized]. Specific character gives some organs as varying. Variations analogous in kind, but less in degree with domesticated animals-chiefly external and less important parts.

Our experience would lead us to expect that any and every one of these organisms would vary if (the organism were) taken away (?) and placed under new conditions. Geology proclaims a constant round of change, bringing into play, by every possible $\langle ?\rangle$ change of climate and the death of pre-existing inhabitants, endless variations of new conditions. These 〈? generally very slow, doubtful though 〈illegible〉 how far the slowness 〈? would produce tendency to vary. But Geolog(ists) show change in configuration which, together with the accidents of air and water and the means of transportal which every being possesses, must occasionally bring, rather suddenly, organism to new conditions and (?) expose it for several generations.

\footnotetext{
1 i.e. they are individually distinguishable.

2 See Origin, Ed. i. p. 133, vi. p. 165.
} 
Hence $\langle ?\rangle$ we should expect every now and then a wild form to vary ${ }^{1}$; possibly this may be cause of some species varying more than others.

According to nature of new conditions, so we might expect all or majority of organisms born under them to vary in some definite way. Further we might expect that the mould in which they are cast would likewise vary in some small degree. But is there any means of selecting those offspring which vary in the same manner, crossing them and keeping their offspring separate and thus producing selected races: otherwise as the wild animals freely cross, so must such small heterogeneous varieties be constantly counter-balanced and lost, and a uniformity of character [kept up] preserved. The former variation as the direct and necessary effects of causes, which we can see can act on them, as size of body from amount of food, effect of certain kinds of food on certain parts of bodies \&c. \&c.; such new varieties may then become adapted to those external [natural] agencies which act on them. But can varieties be produced adapted to end, which cannot possibly influence their structure and which it is absurd to look (at) as effects of chance. Can varieties like some vars of domesticated animals, like almost all wild species be produced adapted by exquisite means to prey on one animal or to escape from another,- or rather, as it puts out of question effects of intelligence and habits, can a plant become adapted to animals, as a plant which cannot be impregnated without agency of insect; or hooked seeds depending on animal's existence: woolly animals cannot have any direct effect on seeds of plant. This point which all theories about

1 When the author wrote this sketch he seems not to have been so fully convinced of the general occurrence of variation in nature as he afterwards became. The above passage in the text possibly suggests that at this time he laid more stress on sports or mutations than was afterwards the case. 
climate adapting woodpecker ${ }^{1}$ to crawl $\langle ?\rangle$ up trees, 〈illegible) miseltoe, 〈sentence incomplete). But if every part of a plant or animal was to vary (illegible), and if a being infinitely more sagacious than man (not an omniscient creator) during thousands and thousands of years were to select all the variations which tended towards certain ends ([or were to produce causes $\langle ?\rangle$ which tended to the same end]), for instance, if he foresaw a canine animal would be better off, owing to the country producing more hares, if he were longer legged and keener sight,greyhound produced ${ }^{2}$. If he saw that aquatic 〈animal would need〉 skinned toes. If for some unknown cause he found it would advantage a plant, which $\langle ?\rangle$ like most plants is occasionally visited by bees \&c.: if that plant's seed were occasionally eaten by birds and were then carried on to rotten trees, he might select trees with fruit more agreeable to such birds as perched, to ensure their being carried to trees; if he perceived those birds more often dropped the seeds, he might well have selected a bird who would (illegible) rotten trees or [gradually select plants which (he) had proved to live on less and less rotten trees]. Who, seeing how plants vary in garden, what blind foolish man has done ${ }^{3}$ in a few years, will deny an all-seeing being in thousands of years could effect (if the Creator chose to do so), either by his own direct foresight or by intermediate means,- which will represent $\langle ?\rangle$ the creator of this universe. Seems usual means. Be it remembered I have nothing' to say about life and mind and all

1 The author may possibly have taken the case of the woodpecker from Buffon, Histoire Nat. des Oiseaux, T. vii. p. 3, 1780, where however it is treated from a different point of view. He uses it more than once, see for instance Origin, Ed. i. pp. 3, 60, 184, vi. pp. 3, 76, 220. The passage in the text corresponds with a diseussion on the woodpecker and the mistletoe in Origin, Ed. i. p. 3, vi. p. 3.

2 This illustration occurs in the Origin, Ed. i. pp. 90, 91, vi. pp. $110,111$.

3 See Origin, Ed. i. p. 83, vi. p. 102, where the word Creator is replaced by Nature. 
forms descending from one common type ${ }^{1}$. I speak of the variation of the existing great divisions of the organised kingdom, how far I would go, hereafter to be seen.

Before considering whether (there) be any natural means of selection, and secondly (which forms the 2nd Part of this sketch) the far more important point whether the characters and relations of animated (things) are such as favour the idea of wild species being races $\langle ?\rangle$ descended from a common stock, as the varieties of potato or dahlia or cattle having so descended, let us consider probable character of [selected races] wild varieties.

Natural Selection. De Candolle's war of nature,seeing contented face of nature,- may be well at first doubted; we see it on borders of perpetual cold $^{2}$. But considering the enormous geometrical power of increase in every organism and as $\langle ?\rangle$ every country, in ordinary cases (countries) must be stocked to full extent, reflection will show that this is the case. Malthus on man,-in animals no moral [check] restraint $\langle ?\rangle$ - they breed in time of year when provision most abundant, or season most favourable, every country has its seasons, - calculate robins,-oscillating from years of destruction ${ }^{3}$. If proof were wanted let any singular change of climate 〈occur $\rangle$ here $\langle ?\rangle$, how astoundingly some tribes $\langle ?\rangle$ increase, also introduced animals, the

1 Note in the original. "Good place to introduce, saying reasons hereafter to be given, how far I extend thcory, say to all mammaliareasons growing weaker and weaker."

${ }_{2}$ See Origin, Ed. i. pp. 62, 63, vi. p. 77, where similar reference is made to De Candolle ; for Malthus see Origin, p. 5.

3 This may possibly refer to the amount of destruction going on. See Origin, Ed. i. p. 68, vi. p. 84, where there is an estimate of a later date as to death-rate of birds in winter. "Calculate robins" probably refers to a calculation of the rate of increase of birds under favourable conditions.

${ }_{4}^{4}$ In the Origin, Ed. i. pp. 64, 65, vi. p. 80, he instances cattle and horses and certain plants in S. America and American species of plants in India, and further on, as unexpected cffects of changed conditions, the enclosure of a heath, and the relation between the fertilisation of clover and the presence of cats (Origin, Ed. i. p. 74, vi. p. 91). 
pressure is always ready,-capacity of alpine plants to endure other climates,-think of endless seeds scattered abroad,--forests regaining their percentage ${ }^{1}$, - a thousand wedges ${ }^{2}$ are being forced into the œconomy of nature. This requires much reflection; study Malthus and calculate rates of increase and remember the resistance,-only periodical.

The unaroidable effect of this (is) that many of every species are destroyed either in egg or [young or mature (the former state the more common)]. In the course of a thousand generations infinitesimally small differences must inevitably tell ${ }^{3}$; when unusually cold winter, or hot or dry summer comes, then out of the whole body of individuals of any species, if there be the smallest differences in their structure, habits, instincts [senses], health \&c., 〈it〉 will on an average tell; as conditions change a rather larger proportion will be preserved: so if the chief check to increase falls on seeds or eggs, so will, in the course of 1000 generations or ten thousand, those seeds (like one with down to $\mathrm{fly}^{4}$ ) which fly furthest and get scattered most ultimately rear most plants, and such small differences tend to be hereditary like shades of expression in human countenance. So if one parent (?) fish deposits its egg in infinitesimally different circumstances, as in rather shallower or deeper water \&c., it will then $\langle ?\rangle$ tell.

Let hares ${ }^{\overline{2}}$ increase very slowly from change of climate affecting peculiar plants, and some other (illegible) rabbit decrease in same proportion [let this unsettle organisation of ], a canine animal, who

1 Origin, Ed. i. p. 74, vi. p. 91. "It has been observed that the trees now growing on...aneient Indian mounds...display the same beautiful diversity and proportion of kinds as in the surrounding virgin forests."

2 The simile of the wedge occurs in the Origin, Ed. i. p. 67 ; it is deleted in Darwin's copy of the first edition : it does not occur in Ed. vi.

${ }^{3}$ In a rough summary at the close of the Essay, occur the words :"Fvery creature lives by a struggle, smallest grain in balance must tell."

4 Cf. Origin, Ed. i. p. 77, vi. p. 94.

5 This is a repetition of what is given at p. 6 . 
formerly derived its chief sustenance by springing. on rabbits or running them by scent, must decrease too and might thus readily become exterminated. But if its form varied very slightly, the long legged fleet ones, during a thousand years being selected, and the less fleet rigidly destroyed must, if no law of nature be opposed to it, alter forms.

Remember how soon Bakewell on the same principle altered cattle and Western, sheep,-carefully avoiding a cross (pigeons) with any breed. We cannot suppose that one plant tends to vary in fruit and another in flower, and another in flower and foliage,--some have been selected for both fruit and flower: that one animal varies in its covering and another not,-another in its milk. Take any organism and ask what is it useful for and on that point it will be found to vary,-cabbages in their leaf,- - corn in size (and) quality of grain, both in times of year,-kidney beans for young pod and cotton for envelope of seeds \&c. \& c.: dogs in intellect, courage, fleetness and smell $\langle$ ? : : pigeons in peculiarities approaching to monsters. This requires consideration,- - should be introduced in first chapter if it holds, I believe it does. It is hypothetical at best $^{1}$.

Nature's variation far less, but such selection far more rigid and scrutinising. Man's races not [even so well] only not better adapted to conditions than other races, but often not $\langle ?\rangle$ one race adapted to its conditions, as man keeps and propagates some alpine plants in garden. Nature lets (an) animal live, till on actual proof it is found less able to do the required work to serve the desired end, man judges solely by his eye, and knows not whether

1 Compare Origin, Ed. i. p. 41, vi. p. 47. "I have seen it gravely remarked, that it was most fortunate that the strawberry began to vary just when gardeners began to attend closely to this plant. No doubt the strawberry had always varied since it was cultivated, but the slight varieties had been neglected." 
nerves, muscles, arteries, are developed in proportion to the change of external form.

Besides selection by death, in bisexual animals (illegible) the selection in time of fullest vigour,namely struggle of males; even in animals which pair there seems a surplus $\langle ?\rangle$ and a battle, possibly as in man more males produced than females, struggle of war or charms ${ }^{1}$. Hence that male which at that time is in fullest vigour, or best armed with arms or ornaments of its species, will gain in hundreds of generations some small advantage and transmit such characters to its offspring. So in female rearing its young, the most vigorous and skilful and industrious, 〈whose) instincts (are) best developed, will rear more young, probably possessing her good qualities, and a greater number will thus $\langle\mathrm{be}\rangle$ prepared for the struggle of nature. Compared to man using a male alone of good breed. This latter section only of limited application, applies to variation of [specific] sexual characters. Introduce here contrast with Lamarck,-absurdity of habit, or chance ?? or external conditions, making a woodpecker adapted to tree ${ }^{2}$.

Before considering difficulties of theory of selection let us consider character of the races produced, as now explained, by nature. Conditions have varied slowly and the organisms best adapted in their whole course of life to the changed conditions have always been selected,-man selects small dog and afterwards gives it profusion of food,-selects a long-backed and short-legged breed and gives it no particular exercise to suit this function \&c. \&c. In ordinary cases nature has not allowed her race to

1 Here we have the two types of sexual selection discussed in the Origin, Ed. i. pp. 88 et seq., vi. pp. 108 et seq.

2 It is not obvious why the author objects to "ehance" or "external eonditions making a woodpeeker." He allows that variation is ultimately referable to eonditions and that the nature of the eonnexion is unknown, i.e. that the result is fortuitous. It is not clear in the original to how nuch of the passage the two ? refer. 
be contaminated with a cross of another race, and agriculturists know how difficult they find always to prevent this,- - effect would be trueness. This character and sterility when crossed, and generally a greater amount of difference, are two main features, which distinguish domestic races from species.

[Sterility not universal admitted by all ${ }^{1}$. Gladiolus, Crinum, Calceolaria must be species if there be such a thing. Races of dogs and oxen: but certainly very general; indeed a gradation of sterility most perfect ${ }^{3}$ very general. Some nearest species will not cross (crocus, some heath $\langle ?\rangle)$, some genera cross readily (fowls ${ }^{4}$ and grouse, peacock \&c.). Hybrids no ways monstrous quite perfect except secretions ${ }^{5}$ hence even the mule has bred,-character of sterility, especially a few years ago $\langle ?\rangle$ thought very much more universal than it now is, has been thought the distinguishing character; indeed it is obvious if all forms freely crossed, nature would be a chaos. But the very gradation of the character, even if it always existed in some degree which it does not, renders it impossible as marks $\langle ?\rangle$ those $\langle ?\rangle$ suppose distinct as species ${ }^{6}$. Will analogy throw any light

1 The meaning is "That sterility is not universal is admitted by all."

2 See Var. under Dom., Ed. 2, i. p. 388, where the garden forms of Gladiolus and Calceolaria are said to be derived from crosscs between distinct speeies. Herbert's hybrid Crinums are discussed in the Origin, Ed. i. p. 250, vi. p. 370. It is well known that the author believed in a multiple origin of domestic dogs.

3 The argument from gradation in sterility is given in the Origin, Ed. i. pp. 248,255 , vi. pp. 368,375 . In the Origin, I liave not come across the eases mentioned, viz. eroeus, heath, or grousc and fowl or peacock. For sterility between elosely allied species, see Origin, Ed. i. p. 257, vi. p. 377. In the present essay thc author does not distinguish between fertility between speeics and the fertility of the hybrid offspring, a point on which he insists in the Origin, Ed. i. p. 245 , vi. p. 365.

4 Ackermann (Ber. d. Vereins $f$. Naturkunde zu Kassel, 1898, p. 23) quotes firom Gloger that a eross has been effected between a domestie hen and a Tetrao tetrix; the offspring died when three days old.

5 No doubt the sexual eells are mcant. I do not know on what evidence it is stated that the mule has bred.

6 The sentence is all but illegiblc. I think that the author refer's to forms usually ranked as varieties having bcen marked as speeics when it was 
on the fact of the supposed races of nature being sterile, though none of the domestic ones are? Mr Herbert (and) Koelreuter have shown external differences will not guide one in knowing whether hybrids will be fertile or not, but the chief circumstance is constitutional differences ${ }^{1}$, such as being adapted to different climate or soil, differences which [must] probably affect the whole body of the organism and not any one part. Now wild animals, taken out of their natural conditions, seldom breed. I do not refer to shows or to Zoological Societies where many animals unite, but (do not ?) breed, and others will never unite, but to wild animals caught and kept quite tame left loose and well fed about houses and living many year's. Hybrids produced almost as readily as pure breds. St Hilaire great distinction of tame and domestic,-elephants,- ferrets ${ }^{2}$. Reproductive organs not subject to disease in Zoological Garden. Dissection and microscope show that liybrid is in exactly same condition as another animal in the intervals of breeding season, or those animals which taken wild and not bred in domesticity, remain without breeding their whole lives. It should be observed that so far from domesticity being unfavourable in itself 〈it) makes more fertile: [when animal is domesticated and breeds, productive power increased from more food and selection of fertile races]. As far as animals go might be thought (an) effect on their mind and a special case.

But turning to plants we find same class of facts. I do not refer to seeds not ripening, perhaps the com-

found that they were sterile together. See the ease of the red and biue Anagallis given from Gärtmer in the Origin, Ed. i. p. 247, vi. p. 368.

1 In the Origin, Ed. i. p. 258, where the author speaks of eonstitutional differenees in this eommexion, he specifies that they are eonfined to the reproduetive system.

2 The sensitiveness of the reproduetive system to ehanged eonditions is insisted on in the Origin, Ed. i. p. 8, vi. p. 10.

The ferret is mentioned, as being prolific in eaptivity, in $V a r$. under Dom., Fd. 2, ii. p. 90. 
monest cause, but to plants not setting, which either is owing to some imperfection of ovule or pollen. Lindley says sterility is the [curse] bane of all propagators,-Linnæus about alpine plants. American bog plants,-pollen in exactly same state as in hybrids,-same in geraniums. Persian and Chinese ${ }^{1}$ lilac will not seed in Italy and England. Probably double plants and all fruits owe their developed parts primarily $\langle ?\rangle$ to sterility and extra food thus $\langle ?\rangle$ applied $^{2}$. There is here gradation (in) sterility and then parts, like diseases, are transmitted hereditarily. We cannot assign any cause why the Pontic Azalea produces plenty of pollen and not American ${ }^{3}$, why common lilac seeds and not Persian, we see no difference in healthiness. We know not on what circumstances these facts depend, why ferret breeds, and cheetah ${ }^{4}$, elephant and pig in India will not.

Now in crossing it is certain every peculiarity in form and constitution is transmitted: an alpine plant transmits its alpine tendency to its offspring, an American plant its American-bog constitution, and (with) animals, those peculiarities, on which ${ }^{5}$ when placed out of their natural conditions they are incapable of breeding; and moreover they transmit every part of their constitution, their

1 Lindley's remark is quoted in the Origin, Ed. i. p. 9. Limneus' remark is to the effect that Alpine plants tend to be sterile under cultivation (see Var. under Dom., Ed. 2, ii. p. 147). In the same place the anthor speaks of peat-loving plants being sterile in our gardens, - no doubt the American bog-plants referred to above. On the following page (p. 148) the sterility of the lilac (Syringa persica and chinensis) is referred to.

2 The author probably means that the increase in the petals is due to a greater food supply being available for them owing to sterility. See the discussion in Var. under Dom., Ed. 2, ii. p. 151. It must be noted that doubleness of the flower may exist without noticeable sterility.

3 I have not come across this case in the autlor's works.

4 For the somewhat doubtful case of the cheetah (Felis jubata) see Var. under Dom., Ed. 2, ii. p. 133. I do not know to what fact "pig in India" refers.

5 This sentence should run "on which depends their incapacity to breed in unnatural conditions." 
respiration, their pulse, their instinct, which are all suddenly modified, can it be wondered at that they are incapable of breeding? I think it may be truly said it would be more wonderful if they did. But it may be asked why have not the recognised varieties, supposed to have been produced through the means of man, [not refused to breed] have all bred ${ }^{1}$. Variation depends on change of condition and selection ${ }^{2}$, as far as man's systematic or unsystematic selection 〈has) gone; he takes external form, has little power from ignorance over internal invisible constitutional differences. Races which have long been domesticated, and have much varied, are precisely those which were capable of bearing great changes, whose constitutions were adapted to a diversity of climates. Nature changes slowly and by degrees. According to many authors probably breeds of dogs are another case of modified species freely crossing. There is no variety which (illegible) has been (illegible) adapted to peculiar soil or situation for a thousand years and another rigorously adapted to another, till such can be produced, the question is not tried ${ }^{3}$. Man in past ages, could transport into different climates, animals and plants which would freely propagate in such new climates. Nature could effect, with selection, such changes slowly, so that precisely those animals which are adapted to submit to great changes have given rise to diverse races,- - and indeed great doubt on this head ${ }^{4}$.

1 This sentence cnds in confision: it should clearly close with the words "refused to breed" in place of the bracket and the present concluding phrase.

2 The author doubtless refers to the change produced by the summation of variation by means of selection.

3 The meaning of this sentence is made clear by a passage in the Ms. of 1844:- "Until man selects two varieties from the same stock, adapted to two cliniates or to other different external conditions, and confines each rigidly for one or several thousand years to such conditions, always selecting the individuals best adapted to them, he cannot be said to have even commenced the experiment." That is, the attempt to produce mutually sterile domestic breeds.

4 This passage is to some extent a repetition of a previous one and may 
Before leaving this subject well to observe that it was shown that a certain amount of variation is consequent on mere act of reproduction, both by buds and sexually,-is vastly increased when parents exposed for some generations to new conditions ${ }^{1}$, and we now find that many animals when exposed for first time to very new conditions, are (as) incapable of breeding as hybrids. It [probably] bears also on supposed fact of crossed animals when not infertile, as in mongrels, tending to vary much, as likewise seems to be the case, when true hybrids possess just sufficient fertility to propagate with the parent breeds and inter se for some generations. This is Koelreuter's belief. 'These facts throw light on each other and support the truth of each other, we see throughout a connection between the reproductive faculties and exposure to changed conditions of life whether by crossing or exposure of the individuals ${ }^{2}$.

Difficulties on theory of selection ${ }^{3}$. It may be objected such perfect organs as eye and ear, could never be formed, in latter less difficulty as gradations more perfect; at first appears monstrous and to 〈the end appears difficulty. But think of gradation, even now manifest, (Tibia and Fibula). Everyone will allow if every fossil preserved, gradation

have been intended to replace an earlier sentence. I have thought it best to give both. In the Origin, Ed. i. p. 141, vi. p. 176, the author gives his opinion that the power of resisting diverse eonditions, seen in man and his domestic animals, is an example "of a very common flexibility of constitution."

1 In the Origin, Ed. i. Chs. I. and v., the author does not admit reproduction, apart from environment, as being a eause of variation. With regard to the eumulative effeet of new eonditions there are many passages in the Origin, Ed. i. e.g. pp. 7, 12, vi. pp. 8, 14.

${ }_{2}$ As already pointed out, this is the important prineiple investigated in the author's Cross and Self-Fertilisation. Professor Bateson has suggested to me that the experiments should be repeated with ganietically pure individuals.

"In the Origin a cliapter is given up to "difficulties on theory": the discussion in the present essay seems slight even when it is remembered how small a space is here available. For Tibia \&c. see p. 48. 
infinitely more perfect; for possibility of selection a perfect $\langle ?\rangle$ gradation is required. Different groups of structure, slight gradation in each group,-every analogy renders it probable that intermediate forms have existed. Be it remembered what strange metamorphoses; part of eye, not directly connected with vision, might come to be[thus used] gradually worked in for this end,--swimming bladder by gradation of structure is admitted to belong to the ear system, -rattlesnake. [Woodpecker best adapted to climb.] In some cases gradation not possible,-as vertebrx, - actually vary in domestic animals,-less difficult if growth followed. Looking to whole animals, a bat formed not for flight ${ }^{1}$. Suppose we had flying fish ${ }^{2}$ and not one of our now called flying fish preserved, who would have guessed intermediate habits. Woodpeckers and tree-frogs both live in countries where no trees ${ }^{3}$.

The gradations by which each individual organ has arrived at its present state, and each individual animal with its aggregate of organs has arrived, probably never could be known, and all present great difficulties. I merely wish to show that the proposition is not so monstrous as it at first appears, and that if good reason can be advanced for believing the species have descended from common parents, the difficulty of imagining intermediate forms of structure not sufficient to make one at once reject the theory.

1 This may be interpreted "The general structure of a bat is the same as that of non-flying mammals."

2 That is truly winged fish.

3 The terrestrial woodpecker of S. Ameriea formed the subject of a paper by Darwin, Proc. Zool. Soc., 1870. See Life and Letters, vol. iii. p. 153. 


\section{$\S$ III. 〈ON VARIATION IN INSTINCTS AND OTHER MENTAL ATTRIBUTES.)}

The mental powers of different animals in wild and tame state [present still greater difficulties] require a separate section. Be it remembered I have nothing to do with origin of memory, attention, and the different faculties of the mind ${ }^{1}$, but merely with their differences in each of the great divisions of

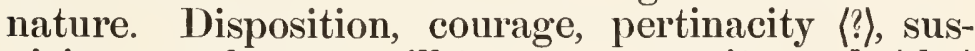
picion, restlessness, ill-temper, sagacity and 〈the〉 reverse unquestionably vary in animals and are inherited (Cuba wildness dogs, rabbits, fear against particular object as man Galapagos ${ }^{2}$ ). Habits purely corporeal, breeding season \&c., time of going to rest \&c., vary and are hereditary, like the analogous habits of plants which vary and are inherited. Habits of body, as manner of movement $d^{\circ}$. and $\mathrm{d}^{\mathrm{o}}$. Habits, as pointing and setting on certain occasions $d^{\circ}$. Taste for hunting certain objects and manner of doing so,-sheep-dog. These are shown clearly by crossing and their analogy with true instinct thus shown,--retriever. Do not know objects for which they do it. Lord Brougham's definition $^{3}$. Origin partly habit, but the amount necessarily unknown, partly selection. Young pointers pointing stones and sheep-tumbling pigeons-sheep ${ }^{4}$ going back to place where born.

1 The same proviso occurs in the Origin, Ed. i. p. 207, vi. p. 319.

2 The tameness of the birds in the Galapagos is described in the Journal of Researches (1860), p. 398. Dogs and rabbits are probably mentioned as cases in which the hereditary fear of man has been lost. In the 1844 Ms. the author states that the Cuban fcral dog shows great natural wildness, cren when caught quite young.

${ }^{3}$ In the Origin, Ed. i. p. 207 , vi. p. 319, lie refuses to define instinct. For Lord Brougham's definition see his Dissertations on Subjects of Science etc., 1839, p. 27.

4 See James Hogg (the Ettrick Shepherd), Works, 1865, Tales and Sketches, p. 403.

D. 
Instinct aided by reason, as in the taylor-bird ${ }^{1}$. 'Taught by parents, cows choosing food, birds singing. Instincts vary in wild state (birds get wilder) often lost $^{2}$; more perfect,-nest without roof. These facts [only clear way] show how incomprehensibly brain has power of transmitting intellectual operations.

Faculties $^{3}$ distinct from true instincts,-finding [way]. It must I think be admitted that habits whether congenital or acquired by practice [sometimes] often become inherited ${ }^{4}$; instincts, influence, equally with structure, the preservation of animals; therefore selection must, with changing conditions tend to modify the inherited habits of animals. If this be admitted it will be found possible that many of the strangest instincts may be thus acquired. I may observe, without attempting definition, that an inherited habit or trick (trick because may be born) fulfils closely what we mean by instinct. A habit is often performed unconsciously, the strangest habits become associated, $\mathrm{d}^{ }$. tricks, going in certain spots \&c. \&c., even against will, is excited by external agencies, and looks not to the end,-a person playing a pianoforte. If such a habit were transmitted it would make a marvellous instinct. Let us consider some of the most difficult cases of instincts, whether they could be possibly acquired. I do not say probably, for that belongs to our 3rd Part ${ }^{5}$, I beg this may be remembered, nor do I mean to attempt to show exact method. I want only to show that

1 This refers to the tailor-bird making use of manufactured thread supplied to it, instead of thread twisted by itself.

$\frac{1}{2}$ Often lost applies to instinct : birds get vilder is printed in a parenthesis because it was apparently added as an after-thought. Nest without roof refers to the water-ousel omitting to vault its nest when building in a proteeted situation.

3 In the Ms. of 1844 is an interesting discussion on faculty as distinct from instinct.

4 At this date and for long afterwards the inhcritance of acquired character's was assumed to oecur.

5 Part II. is here intended: see the Introduction. 
whole theory ought not at once to be rejected on this score.

Every instinct must, by my theory, have been acquired gradually by slight changes (illegible) of former instinct, each change being useful to its then species. Shamming death struck me at first as remarkable objection. I found none really sham death $^{1}$, and that there is gradation; now no one doubts that those insects which do it either more or less, do it for some good, if then any species was led to do it more, and then $\langle ?\rangle$ escaped \&c. \&c.

Take migratory instincts, faculty distinct from instinct, animals have notion of time,-like savages. Ordinary finding way by memory, but how does savage find way across country,-as incomprehensible to us, as animal to them,--geological changes,-fishes in river,--case of sheep in Spain ${ }^{2}$. Architectural instincts,-a manufacturer's employee in making single articles extraordinary skill,-often said seem to make it almost (illegible), child born with such a notion of playing ${ }^{3}$,-we can fancy tailoring acquired in same perfection,-mixture of reason,-water-ouzel,-taylor-bird,-gradation of simple nest to most complicated.

Bees again, distinction of faculty,--how they make a hexagon,-Waterhouse's theory ${ }^{4}$,- the impulse to use whatever faculty they possess,- the taylor-bird has the faculty of sewing with beak, instinct impels him to do it.

Last case of parent feeding young with different food (take case of Galapagos birds, gradation from

1 The meaning is that the attitude assumed in shamming is not accurately like that of death.

2 This lefers to the transandantes sheep mentioned in the Ms. of 1844, as having acquired a migratory instinct.

3 In the Origin, Ed. i. p. 209, vi. p. 321, Mozart's pseudo-instinctive skill in piano-playing is mentioned. See Phil. Trans., 1770, p. 54.

4 In the discussion on bees' cells, Origin, Ed. i. p. 225, vi. p. 343, the author acknowledges that his theory originated in Waterhouse's observations. 
Hawfinch to Sylvia) selection and habit might lead old birds to vary taste $\langle ?\rangle$ and form, leaving their instinct of feeding their young with same food ${ }^{1}$, - or I see no difficulty in parents being forced or induced to vary the food brought, and selection adapting the young ones to it, and thus by degree any amount of diversity might be arrived at. Although we can never hope to see the course revealed by which different instincts have been acquired, for we have only present animals (not well known) to judge of the course of gradation, yet once grant the principle of habits, whether congenital or acquired by experience, being inherited and I can see no limit to the [amount of variation] extraordinariness $\langle ?\rangle$ of the habits thus acquired.

Summing up this Division. If variation be admitted to occur occasionally in some wild animals, and how can we doubt it, when we see [all] thousands $\langle$ of $\rangle$ organisms, for whatever use taken by man, do vary. If we admit such variations tend to be hereditary, and how can we doubt it when we 〈remember) resemblances of features and character, - disease and monstrosities inherited and endless races produced (1200 cabbages). If we admit selection is steadily at work, and who will doubt it, when he considers amount of food on an average fixed and reproductive powers act in geometrical ratio. If we admit that external conditions vary, as all geology proclaims, they have done and are now doing, - then, if no law of nature be opposed, there must occasionally be formed races, [slightly] differing from the parent races. So then any such law', none is

1 Thehawfinch-and Sylvia-typesare figured in the Journal of Researches, p. 379. The discussion of change of form in relation to change of instinct is not clear, and I find it impossible to suggest a paraphrase.

2 I should interpret this obscure sentence as follows, "No such opposing law is known, but in all works on the subject a law is (in flat contradiction to all known facts) assumed to limit the possible amount of variation." In the Origin, the author never limits the power of variation, as far as I know. 
known, but in all works it is assumed, in (?) flat contradiction to all known facts, that the amount of possible variation is soon acquired. Are not all the most varied species, the oldest domesticated: who 〈would) think that horses or corn could be produced? Take dahlia and potato, who will pretend in 5000 years ${ }^{1}$ 〈that great changes might not be effected): perfectly adapted to conditions and then again brought into varying conditions. Think what has been done in few last years, look at pigeons, and cattle. With the amount of food man can produce he may have arrived at limit of fatness or size, or thickness of wool $\langle ?\rangle$, but these are the most trivial points, but even in these I conclude it is impossible to say we know the limit of variation. And therefore with the [adapting] selecting power of nature, infinitely wise compared to those of man, (I conclude) that it is impossible to say we know the limit of races, which would be true $\langle$ to their $\rangle$ kind ; if of different constitutions would probably be infertile one with another, and which might be adapted in the most singular and admirable manner, according to their wants, to external nature and to other surrounding organisms,-such races would be species. But is there any evidence 〈that) species 〈have〉 been thus produced, this is a question wholly independent of all previous points, and which on examination of the kingdom of nature (we) ought to answer one way or another.

1 In Var. under Dom. Ed. 2, ii. p. 263, the Dahlia is described as showing sensitiveness to conditions in 1841. All the varieties of the Dahlia are said to have arisen since 1804 (ibid. i. p. 393). 


\section{PART II ${ }^{1}$.}

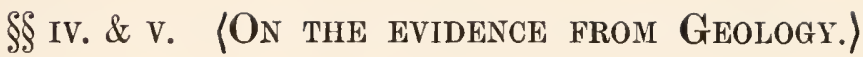

I may premise, that according to the view ordinarily received, the myriads of organisms peopling this world have been created by so many distinct acts of creation. As we know nothing of the (illegible) will of a Creator,-we can see no reason why there should exist any relation between the organisms thus created; or again, they might be created according to any scheme. But it would be marvellous if this scheme should be the same as would result from the descent of groups of organisms from [certain] the same parents, according to the circumstances, just attempted to be developed.

With equal probability did old cosmogonists say fossils were created, as we now see them, with a false resemblance to living beings ${ }^{2}$; what would the Astronomer say to the doctrine that the planets moved (not) according to the law of gravitation, but from the Creator having willed each separate planet to move in its particular orbit? I believe such a proposition (if we remove all prejudices) would be as legitimate as to admit that certain groups of living and extinct organisms, in their distribution, in their structure and in their relations one to another and to external conditions, agreed with the theory

1 In the original Ms. the heading is: Part III. ; but Part II. is elearly intended; for details see the Introduetion. I have not been able to discover where $\$ \mathrm{Iv}$. ends and $\$ \mathrm{v}$. begins.

${ }^{2}$ This passage eorresponds roughly to the conelusion of the Origin, see Ed. i. p. 482 , vi. p. 661 . 
and showed signs of common descent, and yet were created distinct. As long as it was thought impossible that organisms should vary, or should anyhow become adapted to other organisms in a complicated manner, and yet be separated from them by an impassable barrier of sterility ${ }^{1}$, it was justifiable, even with some appearance in favour of a common descent, to admit distinct creation according to the will of an Omniscient Creator; or, for it is the same thing, to say with Whewell that the beginnings of all things surpass the comprehension of man. In the former sections I have endeavoured to show that such variation or specification is not impossible, nay, in many points of view is absolutely probable. What then is the evidence in favour of it and what the evidence against it. With our imperfect knowledge of past ages [surely there will be some] it would be strange if the imperfection did not create some unfavourable evidence.

Give sketch of the Past,-beginning with facts appearing hostile under present knowledge,--then proceed to geograph. distribution,- order of appearance,--affinities,-morphology \& c., \& c.

Our theory requires a very gradual introduction of new forms ${ }^{2}$, and extermination of the old (to which we shall revert). The extermination of old may sometimes be rapid, but never the introduction. In the groups descended from common parent, our theory requires a perfect gradation not differing more than breed/s〉 of cattle, or potatoes, or cabbages in forms. I do not mean that a graduated series of animals must have existed, intermediate between horse, mouse, tapir ${ }^{3}$, elephant [or fowl and peacock],

1 A similar passage occurs in the conclusion of the Origin, Ed. i. p. 481, vi. p. 659 .

See Origin, Ed. i. p. 312 , vi. p. 453.

3 See Origin, Ed. i. pp. 280, 281 , vi. p. 414. The author uses his experience of pigeons for examples for what he means by intermediate; the instance of the horse and tapir also occurs. 
but that these must have had a common parent, and between horse and this $\langle ?\rangle$ parent \&c., \& c., but the common parent may possibly have differed more from either than the two do now from each other. Now what evidence of this is there? So perfect gradation in some departments, that some naturalists have thought that in some large divisions, if all existing forms were collected, a near approach toperfect gradation would be made. But such a notion is preposterous with respect to all, but evidently so with mammals. Other naturalists have thought this would be so if all the specimens entombed in the strata were collected ${ }^{1}$. I conceive there is no probability whatever of this ; nevertheless it is certain all the numerous fossil forms fall in $\langle$ to $\rangle$, as Buckland remarks, not present classes, families and genera, they fall between them: so is it with new discoveries of existing forms. Most ancient fossils, that is most separated (by) space of time, are most apt to fall between the classes-(but organisms from those countries most separated by space also fall between the classes $\langle e . g$.$\rangle Ornithorhyncus?). As far as geological$ discoveries $\langle\mathrm{go}\rangle$ they tend towards such gradation ${ }^{2}$. Illustrate it with net. Toxodon,- - tibia and fibula,dog and otter,- -but so utterly improbable is $\langle i t\rangle$, in ex. gr: Pachydermata, to compose series as perfect as cattle, that if, as many geologists seem to

1 The abscnee of intermediate forms between living organisms (and also as regards fossils) is discussed in the Origin, Ed. i. pp. 279, 280, vi. p. 413. In the above discussion there is no evidence that tle author felt this difficulty so strongly as it is expressed in the Origin, Ed. i. p. 299,-as perhaps "the most obvious and gravest objection that can be urged against my theory." But in a rough summary written on the baek of the penultimate page of the MS. he refers to the geological cvidencc:- "Evidence, as far as it does go, is favourable, exceedingly incomplete, - greatest diffieulty on this theory. I am convineed not insuperable." Buekland's remarks are given in the Origin, Ed. i. p. 329, vi. p. 471.

2 That the evidenee of geology, as far as it goes, is favourable to the theory of descent is elaimed in the Origin, Ed. i. pp. $343-345$, vi. pp. 490 -492 . For the reference to net in the following sentence, see Note 1, p. 48, of this Essay. 
infer, each separate formation presents even an approach to a consecutive history, my theory must be given up. Even if it were consecutive, it would only collect series of one district in our present state of knowledge; but what probability is there that any one formation during the immense period which has elapsed during each period will generally present a consecutive history. [Compare number living at one period to fossils preserved-look at enormous periods of time.]

Referring only to marine animals, which are obviously most likely to be preserved, they must live where $\langle ?\rangle$ sediment (of a kind favourable for preservation, not sand and pebble $)^{1}$ is depositing quickly and over large area and must be thickly capped, 〈illegible) littoral deposits: for otherwise denudation (will destroy them),- they must live in a shallow space which sediment will tend to fill up,-as movement

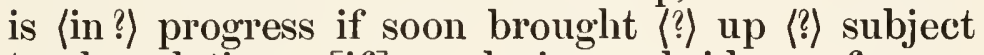
to denudation,-- iff] as during subsidence favourable, accords with facts of European deposits ${ }^{2}$, but subsidence apt to destroy agents which produce sediment $^{3}$.

I believe safely inferred 〈that groups of marine 〈? fossils only preserved for future ages where sediment goes on long (and) continuous(ly) and with rapid but not too rapid deposition in (an) area of subsidence. In how few places in any one region like Europe will $\langle ?\rangle$ these contingencies be going on? Hence $\langle ?\rangle$ in

1 Scc Origin, Ed. i. p. 28s, vi. p. 422. "The remains that do become embedded, if in sand and gravel, will, when the beds are upraised, generally be dissolved by the percolation of rain-water."

2 The position of the following is not clear:- "Think of immense differcnces in nature of European deposits,-without intcrposing new causes, - think of time required by present slow changes, to cause, on very same arca, such diverse deposits, iron-sand, chalk, sand, coral, clay!"

3 The paragraph which ends here is difficult to interpret. In spite of obscurity it is easy to recognize the general resemblance to the discussion on the importance of subsidence given in the Origin, Ed. i. pp. 290 et seq., vi. pp. 422 et seq. 
past ages mere [gaps] pages preserved ${ }^{1}$. Lyell's doctrine carried to extreme,-we shall understand difficulty if it be asked:- what chance of series of gradation between cattle by (illegible)at age(illegible) as far back as Miocene ${ }^{2}$ ? We know then cattle existed. Compare number of living,-immense duration of each period,-fewness of fossils.

This only refer's to consecutiveness of history of organisms of each formation.

The foregoing argument will show firstly, that formations are distinct merely from want of fossils 〈of intermediate beds), and secondly, that each formation is full of gaps, has been advanced to account for fewness of preserved organisms compared to what have lived on the world. The very same argument explains why in older formations the organisms appear to come on and disappear suddenly,-but in [later] tertiary not quite suddenly ${ }^{3}$, in later tertiary gradually,-becoming rare and disappearing,-some have disappeared within inan's time. It is obvious that our theory requires gradual and nearly uniform introduction, possibly more sudden extermination,-subsidence of continent of Australia \&c., \&c.

Our theory requires that the first form which existed of each of the great divisions would present points intermediate between existing ones, but immensely different. Most geologists believe Silurian ${ }^{4}$ fossils are those which first existed in the whole world,

1 See Note 3, p. 27.

2 Compare Origin, Ed. i. p. 298, vi. p. 437. "We shall, perhaps, best perceive the improbability of our being enabled to comnect species by numerous, fine, intermediate, fossil links, by asking ourselves whether, "for" instance, geologists at some future period will be able to prove that our different breeds of cattle, sheep, horses, and dogs have descended from a single stock or from several aboriginal stocks."

3 The sudden appearance of groups of allied species in the lowest known fossiliferous strata is discussed in the Origin, Ed. i. p. 306, vi. p. 446. The gradual appearance in the later strata occurs in the Origin, Ed. i. p. 312 , vi. p. 453 .

4 Compare Origin, Ed. i. p. 307 , vi. p. 448. 
not those which have chanced to be the oldest not destroyed,-or the first which existed in profoundly deep seas in progress of conversion from sea to land: if they are first they (? we) give up. Not so Hutton or Lyell : if first reptile ${ }^{1}$ of Red Sandstone (??) really was first which existed: if Pachyderm² of Paris was first which existed : fish of Devonian: dragon fly of Lias : for we cannot suppose them the progenitors: they agree too closely with existing divisions. But geologists consider Europe as 〈? $\rangle$ a passage from sea to island $\langle ?\rangle$ to continent (except Wealden, see Lyell). These animals therefore, I consider then mere introduction $\langle ?\rangle$ from continents long since submerged.

Finally, if views of some geologists be correct, my theory must be given up. [Lyell's views, as far as they go, are in favour, but they go so little in favour, and so much more is required, that it may $\langle\mathrm{be}\rangle$ viewed as objection.] If geology present us with mere pages in chapters, towards end of $\langle a\rangle$ history, formed by tearing out bundles of leaves, and each page illustrating merely a small portion of the organisms of that time, the facts accord perfectly with my theory ${ }^{3}$.

1 I lave interpreted as Sandstone a scrawl which I first read as Sea; I have done so at the suggestion of Professor Judd, who points out that "footprints in the red sandstone were known at that time, and geologists were not then particular to distinguish between Amphibians and Reptiles."

2 This refers to Cuvier's diseovery of Palcotherium \&c. at Montmartre.

3 This simile is more fully given in the Origin, Ed. i. p. 310, vi. p. 452. "For my part, following ont Lyell's metaphor;, I look at the natural geologieal record, as a history of the world imperfectly kept, and written in a changing dialect; of this history we possess the last volume alone, relating only to two or three countries. Of this volume, only here and there a short cliapter has been preserved; and of each page, only here and there a few lines. Hach word of the slowly-ehanging language, in which the history is supposed to be written, being more or less different in the interrupted succession of ehapters, may represent the apparently abruptly changed forms of life, entombed in our conseentive, but widely separated formations." Professor Judd has been good enough to point out to me, that Darwin's metaphor is founded on the eomparison of geology to history in Ch. i. of the Principles of Geology, Ed. i. 1830, vol. i. pp. 1-4. Professor. Judd has also ealled my attention to another passage,-Principles, El. i. 1833, vol. iii. p. 33, when Lyell imagines an historian examining "two buried eities at the foot of Vesuvius, immediately superimposed upon each 
Extermination. We have seen that in later periods the organisms have disappeared by degrees and [perhaps] probably by degrees in earlier, and I have said our theory requires it. As many naturalists seem to think extermination a most mysterious circumstance ${ }^{1}$ and call in astonishing agencies, it is well to recall what we have shown concerning the struggle of nature. An exterminating agency is at work with every organism : we scarcely see it: if robins would increase to thousands in ten years how severe must the process be. How imperceptible a small increase: fossils become rare: possibly sudden extermination as Australia, but as present means very slow and many means of escape, I shall doubt very sudden exterminations. Who can explain why some species abound more,--why does marsh titmouse, or ring-ouzel, now little change,--why is one sea-slug rare and another common on our coasts,-why one species of Rhinoceros more than another,-why is 〈illegible) tiger of India so rare? Curious and general sources of error, the place of an organism is instantly filled up.

We know state of earth has changed, and as earthquakes and tides go on, the state must change,-many geologists believe a slow gradual cooling. Now let us see in accordance with principles of [variation] specification explained in Sect. II. how species would probably be introduced and how such results accord with what is known.

other." The historian would discover that the inhabitants of the lower town were Grceks while those of the upper one were Italians. But lie would be wrong in supposing that there liad bcen a sudden cliange from the Greek to the Italian language in Campania. I think it is clear that Darwin's metaphor is partly taken from this passage. Sec for instance (in the above passage from the Origin) such phrases as "history... written in a changing dialect"- "apparently abruptly changed forms of life." The passage within [] in the above paragrapll:- "Lyell's views as far as they go \&c.," no doubt refers, as Professor Judd points out, to Lyell not going so far as Darwin on the question of the imperfection of the geological record.

1 On rarity and extinction see Origin, Ed. i. pp. 109, 319, vi. pp. 133, 461. 
The first fact geology proclaims is immense number of extinct forms, and new appearances. Tertiary strata leads to belief, that forms gradually become rare and disappear and are gradually supplied by others. We see some forms now becoming rare and disappearing, we know of no sudden creation: in older periods the forms appear to come in suddenly, scene shifts: but even here Devonian, Permian \&c. [keep on supplying new links in chain]--Genera and higher forms come on and disappear, in same way leaving a species on one or more stages below that in which the form abounded.

\section{〈Geographical Distribution.)}

$\S$ vI. Let us consider the absolute state of distribution of organisms of earth's face.

Referring chiefly, but not exclusively (from difficulty of transport, fewness, and the distinct characteristics of groups) to Mammalia; and first considering the three or four main [regions] divisions; North America, Europe, Asia, including greater part of E. Indian Archipelago and Africa are intimately allied. Africa most distinct, especially most southern parts. And the Arctic regions, which unite N. America, Asia and Europe, only separated (if we travel one way by Behring's St.) by a narrow strait, is most intimately allied, indeed forms but one restricted group. Next comes S. America,- then Australia, Madagascar (and some small islands which stand very remote from the land). Looking at these main divisions separately, the organisms vary according to changes in condition ${ }^{1}$ of different parts. But besides this, barriers of every kind seem to separate

\footnotetext{
1 In the Origin, Ed. i. p. 346, vi. p. 493, the author begins his discussion on geographical distribution by minimising the effect of physical conditions. He lays great stress on the effect of barriers, as in the present Essay.
} 
regions in a greater degree than proportionally to the difference of climates on each side. Thus great chains of mountains, spaces of sea between islands and continents, even great rivers and deserts. In fact the amount $\langle$ of $\rangle$ difference in the organisms bears a certain, but not invariable relation to the amount of physical difficulties to transit'.

There are some curious exceptions, namely, similarity of fauna of mountains of Europe and N. America and Lapland. Other cases just $\langle$ the $\rangle$ reverse, mountains of easter'n S. America, Altai (?), S. India (?) $)^{2}$ : mountain summits of islands often eminently peculiar. Fauna generally of some islands, even when close, very dissimilar, in others very similar. [I am here led to observe one or more centres of creation $^{3}$.]

The simple geologist can explain many of the foregoing cases of distribution. Subsidence of a continent in which free means of dispersal, would drive the lowland plants up to the mountains, now converted into islands, and the semi-alpine plants would take place of alpine, and alpine be destroyed, if mountains originally were not of great height. So we may see, during gradual changes ${ }^{4}$ of climate on a continent, the propagation of species would vary and adapt themselves to small changes

1 Note in the original, "Would it be more striking if we took animals, take Rhinoceros, and study their habitats?"

2 Note by Mr A. R. Wallaee. "The want of similarity referred to, is, between the mountains of Brazil and Guiana and those of the Andes. Also those of the Indian peninsula as compared with the Himalayas. In both cases there is continuous intervening land.

"The islands referred to were, no doubt, the Galapagos for" dissimilarity from S. Ameriea; our own Islands as compared with Europe, and perhaps Java, for similarity with continental Asia."

3 The arguments against multiple centres of creation are given in the Origin, Ed. i. p. 352, vi. p. 499.

4 In the Origin, Ed. i. p. 366 , vi. p. 516 , the anthor does not give his views on the distribution of alpine plants as original but refers to Edward Forbes' work (Geolog. Survey Memoirs, 1846). In his autobiography, Darwin refers to this. "I was forestalled" he says, "in only one important point, whieh my vanity has always made me regret." (Life and Letters, i. p. 88.) 
causing much extermination ${ }^{1}$. The mountains of Europe were quite lately covered with ice, and the lowlands probably partaking of the Arctic climate and Fauna. Then as climate changed, arctic fauna would take place of ice, and an inundation of plants from different temperate countries (would) seize the lowlands, leaving islands of arctic forms. But if this had happened on an island, whence could the new forms have come,- - here the geologist calls in creationists. If island formed, the geologist will suggest 〈that〉 many of the forms might have been borne from nearest land, but if peculiar, he calls in creationist,as such island rises in height \&c., he still more calls in creation. The creationist tells one, on a 〈illegible) spot the American spirit of creation makes Orpheus and Tyrannes and American doves, and in accordance with past and extinct forms, but no persistent relation between areas and distribution, GeologicoGeograph.-Distribution.

1 〈The following is written on the back of a page of the Ms.) Diseuss one or more centres of ereation : allude strongly to faeilities of dispersal and amount of geological ehange: allude to mountain-summits afterwards to be referred to. The distribution varies, as everyone knows, aceording to adaptation, explain going from $\mathrm{N}$. to $\mathrm{S}$. how we come to fresh groups of speeies in the same general region, but besides this we find differenee, aceording to grcatness of barriers, in greater proportion than ean be well aecounted for by adaptation. 〈On representive speeies see Origin, Ed. i. p. 349 , vi. p. 496. This very striking when we think of eattle of Pampas, plants $\langle$ ? $\rangle$ \&e. \&c. Then go into discussion; this holds with 3 or 4 nain divisions as well as the endless minor ones in each of these 4 great ones: in these I ehiefly refer to mammalia \&e. \&c. The similarity of type, but not in species, in same eontinent has been much less insisted on than the dissimilarity of different great regions generieally: it is more striking.

〈I have here omitted an incomprehensible sentenee.) Galapagos Islands, Tristan d'Acunha, volcanic islands covered with craters we know lately did not support any organisms. How unlike these islands in nature to neighbouring lands. These facts perhaps more striking than almost any others. [Geology apt to affeet geography therefore we ought to expeet to find the above.] Geological-geographical distribution. In looking to past times we find Australia equally distinet. S. America was distinet, though with more forms in eommon. N. Ameriea its nearest neighbour more in eommon, -in some respects more, in some less allied to Europe. Europe we find $\langle ?\rangle$ equally European. For Europe is now part of Asia though not (illegible). Afriea unknown,--examples, Elephant, Rhinoceros, Hippopotamus, Hyaena. As geology destroys geography we eamot be surprised in going far back we find Marsupials and Edentata in Europe : but geology destroys geography. 
Now according to analogy of domesticated animals let us see what would result. Let us take case of farmer on Pampas, where everything approaches nearer to state of nature. He works on organisms having strong tendency to vary: and he knows (that the) only way to make a distinct breed is to select and separate. It would be useless to separate the best bulls and pair with best cows if their offspring run loose and bred with the other herds, and tendency to reversion not counteracted; he would endeavour therefore to get his cows on islands and then commence his work of selection. If several farmers in different rincons' ${ }^{1}$ were to set to work, especially if with different objects, several breeds would soon be produced. So would it be with horticulturist and so history of every plant shows; the number of varieties ${ }^{2}$ increase in proportion to care bestowed on their selection and, with crossing plants, separation. Now, according to this analogy, change of external conditions, and isolation either by chance landing $\langle o f\rangle$ a form on an island, or subsidence dividing a continent, or great chain of mountains, and the number of individuals not being numerous will best favour variation and selection ${ }^{3}$. No doubt change could be effected in same country without any barrier by long continued selection on one species: even in case of a plant not capable of crossing would easier get possession and solely

${ }^{1}$ Rincon in Spanish means a nook or corner, it is here probably used to mean a small farm.

2 The following is written across the page : "No one would expect a set of similar varieties to be produced in the different countries, so species different."

3 (The following passage seems to have been meant to follow here.) The parent of an organism, we may generally suppose to be in less favourable condition than the selected offspring and therefore generally in fewer numbers. (This is not borne out by horticulture, mere hypothesis; as an organism in favourable conditions might by selection be adapted to still more favourable conditions.)

Barrier would further act in preventing species formed in one part migrating to another part. 
occupy an island ${ }^{1}$. Now we can at once see that $\langle$ if $\rangle$ two parts of a continent isolated, new species thus generated in them, would have closest affinities, like cattle in counties of England: if barrier afterwards destroyed one species might destroy the other or both keep their ground. So if island formed near continent, let it be ever so different, that continent would supply inhabitants, and new species (like the old) would be allied with that continent. An island generally very different soil and climate, and number and order of inhabitants supplied by chance, no point so favourable for generation of new species ${ }^{2}$,especially the mountains, hence, so it is. As isolated mountainsformed in a plain country(if such happens) is an island. As other islands formed, the old species would spread and thus extend and the fauna of distant island might ultimately meet and a continent formed between them. No one doubts continents formed by repeated elevations and depressions ${ }^{3}$. In looking backwards, but not so far that all geographical boundaries are destroyed, we can thus at once see why existing forms are related to the extinct in the same manner as existing ones are in some part of existing continent. By chance we might even have one or two absolute parent fossils.

The detection of transitional forms would be rendered more difficult on rising point of land.

The distribution therefore in the above enumer-

1 (The following notes occur on the back of the page.) Number of species not related to capabilities of the country : furthermore not always those best adapted, perhaps explained by creationists by changes and progress. 〈See p. 34 , note 1.)

Although creationists can, by help of geology, explain much, how can he explain the marked relation of past and present in same area, the varying relation in other cases, between past and present, the relation of different parts of same great area. If island, to adjoining continent, if quite different, on mountain summits, - the number of individuals not being related to capabilities, or how \&c.-our theory, I believc, can throw much light and all facts accord.

2 See Origin, Ed. i. p. 390 , vi. p. 543.

3 On oscillation see Origin, Ed. i. p. 291, vi. p. 426.

D. 
ated points, even the trivial ones, which on any other (theory ?) can be viewed as so many ultimate facts, all follow (in) a simple manner on the theory of the occurrence of species by (illegible) and being adapted by selection to (illegible), conjoined with their power of dispersal, and the steady geographicogeological changes which are now in progress and which undoubtedly have taken place. Ought to state the opinion of the immutability of species and the creation by so many separate acts of will of the Creator ${ }^{1}$.

1 〈From the back of MS.) Effect of climate on stationary island and on continent, but continent once island. Moreover repeated oscillations fresh diffusion when non-united, then isolation, when rising again immigration prevented, new habitats formed, new species, when united frec immigration, hence uniform characters. Hence nore forms 〈on ?〉 the island. Mountain summits. Why not true species. First let us recall in Part I, conditions of variation : change of conditions during several gencrations, and if frequently altered so much better [pcrhaps excess of food]. Secondly, continued selection [while in wild state]. Thirdly, isolation in all or nearly all,- - as well to recall advantages of.

[In continent, if we look to terrestrial animal, long continued change might go on, which would only cause cliange in numerical number 〈? proportions): if continued long enough might ultimately affect all, though to most continents 〈there is〉 chance of immigration. Some few of whole body of species must be long affected and cntire selection working same way. But here isolation absent, without barrier, cut off such 〈illegible〉. We can see advantage of isolation. But let us take case of island thrown up by volcanic agency at some distances, here we should lrave occasional visitants, only in few numbers and exposed to new conditions and 〈illegible) more important, - a quite new grouping of organic beings, which would

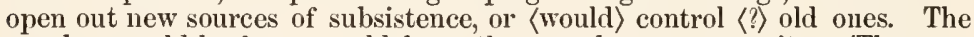
number would be few, can old have the very best opportunity. 〈The conquest of the indigenes by introduced organisms shows that the indigenes were not perfectly adapted, see Origin, Ed. i. p. 390.) Moreover as the island continued changing,-continued slow changes, river, marshes, lakes, mountains \&c. \&c., new races as successively formed and a fresh occasional visitant.

If island formed contincut, some spccies would emerge and immigrate. Everyone admits contincnts. We can see why Galapagos and C. Verde differ (see Origin, Ed. i. p. 398)], depressed and raised. We can see from this repeated action and tle time required for a continent, why many more forms than in New Zealand (sce Origin, Ed. i. p. 389 for a comparison between New Zealand and the Cape) no mammals or other classes 〈sce however, Origin, Ed. i. p. 393 for the case of the frog). We can at once see low it comes when there lias been an old channel of migration,-Cordilleras; we can sec why Indian Asiatic Flora, - [why species] having a wide range gives better chance of some arriving at new points and being selected, and adapted to new ends. I need hardly remark no necessity for change. 


\section{$\S$ vil. 〈Affinities and Classification.)}

Looking now to the affinities of organisms, without relation to their distribution, and taking all fossil and recent, we see the degrees of relationship are of different degrees and arbitrary,-sub-genera, - genera,-sub-families, families, orders and classes and kingdoms. The kind of classification which everyone feels is most correct is called the natural system, but no can define this. If we say with Whewell (that we have an) undefined instinct of the importance of organs ${ }^{1}$, we have no means in lower

Finally, as continent (most extinction $\langle ?\rangle$ during formation of continent) is formed after repeated elevation and depression, and intcrchange of species we might foretell much extinction, and that the survivor wonld belong to same type, as the extinct, in same manner as different part of same continent, which were once separated by space as they are by time (see Origin, Ed. i. pp. 339 and 349 ).

As all mammals have descended from one stock, we ought to expect that every continent has been at some timc connected, hence obliteration of present ranges. I do not mean that the fossil mammifers found in S. America are the lincal snccessor's 〈ancestors〉 of the present forms of S. America : for it is highly improbable that more than one or two cases (who will say how many races after Plata bones) slould be found. I believe this from numbers, who have lived, - mere $\langle ?\rangle$ chance of fewness. Moreover in every casc from very existence of genera and species only few at one time will leave progeny, under form of new species, to distant ages; and the more distant the ages the fewer the progenitors. An observation may be here appended, bad chance of preservation on rising island, the nurseries of new species, appcal to expcrience 〈see Origin, Ed. i. p. 292). This observation may be extended, that in all cases, subsiding land must be, in early stages, less favourable to formation of ncw species; but it will isolate them, and then if land recommences rising how favonrable. As preoccupation is bar to diffusion to species, so would it be to a selected varicty. But it would not be if that variety was better fittcd to some not fully occupied station; so during clevation or the formation of new stations, is scene for llew species. But during elevation not favourable to preservation of fossil (except in caverns $\langle ?\rangle$ ); when subsidence highly favourable in early stages to preservation of fossils; when subsidence, less scdiment. So that our strata, as general rule will be the tomb of old species (not nudergoing any change) when rising land the nursery. But if there be vestige will gencrally be preserved to future ages, the new ones will not be entombed till fresh subsidence supervenes. In this long gap wc sliall liave no record: so that wonderful if we should get transitional forms. I do not mean every stage, for we cannot expect that, as before shown, until geologists will be prepared to say that although under unnaturally favourable condition we can trace in future ages short-horn and Herefordshire 〈sec note 2, p. 26).

1 After "organs" is inserted, apparently as an afterthought :- "no, and instance metamorphosis, afterwards explicable." 
animals of saying which is most important, and yet everyone feels that some one system alone deserves to be called natural. The true relationship of organisms is brought before one by considering relations of analogy, an otter-like animal amongst mammalia and an otter amongst marsupials. In such cases external resemblance and habit of life and the final end of whole organization very strong, yet no relation ${ }^{1}$. Naturalists cannot avoid these terms of relation and affinity though they use them metaphorically. If used in simple earnestness the natural system ought to be a genealogical (one); and our knowledge of the points which are most easily affected in transmission are those which we least value in considering the natural system, and practically when we find they do vary we regard them of less value ${ }^{2}$. In classifying varieties the same language is used and the same kind of division: here also (in pine-apple) ${ }^{3}$ we talk of the natural classification, overlooking similarity of the fruits, because whole plant differs. The origin of sub-genera, genera, \&c., \&c., is not difficult on notion of genealogical succession, and accords with what we know of similar gradations of affinity in domesticated organisms. In the same region the organic beings are (illegible) related to each other and the external conditions in many physical respects are allied ${ }^{4}$ and their differences of same kind, and therefore when a new species has been selected and has obtained a place in the economy of nature, we

1 For analogieal resenublanees see Origin, Ed. i. p. 427 , vi. p. 582.

2 "Praetieally when naturalists are at work, they do not trouble themselves about the plysiological value of the eharaeters.... If they find a character nearly uniform,...they use it as one of high value," Origin, Ed. i. p. 417 , vi. p. 573 .

3 "We are cantioned...not to elass two varieties of the pine-apple together, nerely because their fruit, though the most important part, lappens to be nearly identical," Origin, Ed. i. p. 423, vi. p. 579.

The whole of this passage is obseure, but the text is quite clear, exeept for one illegible word. 
may suppose that generally it will tend to extend its range during geographical changes, and thus, becoming isolated and exposed to new conditions, will slightly alter and its structure by selection become slightly remodified, thus we should get species of a sub-genus and genus, - as varieties of merinosheep,- - varieties of British and Indian cattle. Fresh species might go on forming and others become extinct and all might become extinct, and then we should have 〈an〉 extinct genus; a case formerly mentioned, of which numerous cases occur in Palæontology. But more often the same advantages which caused the new species to spread and become modified into several species would favour some of the species being preserved: and if two of the species, considerably different, each gave rise to group of new species, you would have two genera; the same thing will go on. We may look at case in other way, looking to future. According to mere chance every existing species may generate another, but if any species, $A$, in changing gets an advantage and that advantage (whatever it may be, intellect, \&c., \&c., or some particular structure or constitution) is inherited ${ }^{1}, A$ will be the progenitor of several genera or even families in the hard struggle of nature. A will go on beating out other forms, it might come that $A$ would people earth,-we may now not have one descendant on our globe of the one or several original creations ${ }^{2}$. External conditions air, earth, water being same ${ }^{3}$ on globe, and the communication not being perfect, organisms of widely different descent might become adapted to

1 〈The exact position of the following passage is uncertain :) "just as it is not likely every present breed of fancy birds and cattle will propagate, only some of the best."

2 This suggests that the author was not far from the principle of divergence on which he afterwards laid so mucl stress. See Origin, Ed. i. p. 111 , vi. p. 134, also Life and Letters, i. p. 84.

3 That is to say the same conditions occurring in different parts of the globe. 
the same end and then we should have cases of analogy ${ }^{1}$, [they might even tend to become numerically representative]. From this often happening each of the great divisions of nature would have their representative eminently adapted to earth, to $\langle\text { air }\rangle^{2}$, to water, and to these in 〈illegible these great divisions would show numerical relations in their classification.

\section{§ VIII. UNITY [OR SIMILARITY] OF TYPE IN THE GREAT CLASSES.}

Nothing more wonderful in Nat. Hist. than looking at the vast number of organisms, recent and fossil, exposed to the most diverse conditions, living in the most distant climes, and at immensely remote periods, fitted to wholely different ends, yet to find large groups united by a similar type of structure. When we for instance see bat, horse, porpoise-fin, hand, all built on same structure ${ }^{3}$, having bones ${ }^{4}$ with same name, we see there is some deep bond of union between them ${ }^{5}$, to illustrate this is the foundation and objects $\langle ?\rangle\langle$ of $\rangle$ what is called the Natural System; and which is foundation of distinction $\langle ?\rangle$ of true and adaptive characters ${ }^{6}$. Now this wonderful fact of hand, hoof, wing, paddle and claw being the same, is at once explicable on the principle of some parentforms, which might either be (illegible) or walking animals, becoming through infinite number of small

1 The position of the following is uncertain, "greyhound and racehorse have an analogy to each other." The same comparison occurs in the Origin, Ed. i. p. 427 , vi. p. 583.

${ }^{2} \mathrm{Air}$ is evidently intended; in the Ms. water is written twice.

3 Written between the lines occurs:- "extend to birds and other classes."

4 Written between the lines occurs:-"many bones merely represented."

${ }^{5}$ In the Origin, Ed. i. p. 434 , vi. p. 595 , the term morphology is taken as including unity of type. The paddle of the porpoise and the wing of the bat are there used as instances of morphological resemblance.

6 The sentence is difficult to decipher. 
selections adapted to various conditions. We know that proportion, size, shape of bones and their accompanying soft parts vary, and hence constant selection would alter, to almost any purpose $\langle ?\rangle$ the framework of an organism, but yet would leave a general, even closest similarity in it.

[We know the number of similar parts, as vertebræ and ribs can vary, hence this also we might expect.] Also (if) the changes carried on to a certain point, doubtless type will be lost, and this is case with Plesiosaurus ${ }^{1}$. The unity of type in past and present ages of certain great divisions thus undoubtedly receives the simplest explanation.

There is another class of allied and almost identical facts, admitted by the soberest physiologists, [from the study of a certain set of organs in a group of organisms] and refers (? referring $\rangle$ to a unity of type of different organs in the same individual, denominated the science of "Morphology." The 〈? this〉 discovered by beautiful and regular series, and in the case of plants from monstrous changes, that certain organs in an individual are other organs metamorphosed. Thus every botanist considers petals, nectaries, stamens, pistils, germen as metamorphosed leaf. They thus explain, in the most lucid manner, the position and number of all parts of the flower, and the curious conversion under cultivation of one part into another. The complicated double set of jaws and palpi of crustaceans ${ }^{2}$, and all insects are considered as metamorphosed (limbs) and to see the series is to admit this phraseology. The skulls of the vertebrates are undoubtedly composed of three metamorphosed vertebræ; thus we can understand the strange form of

1 In the Origin, Ed. i. p. 436, vi. p. 598, the author speaks of the "general pattern" being obscured in the paddles of "extinct gigantic sealizards."

${ }^{2}$ See Origin, Ed. i. p. 437, vi. p. 599. 
the separate bones which compose the casket holding man's brain. These ${ }^{1}$ facts differ but slightly from those of last section, if with wing, paddle, hand and hoof, some common structure was yet visible, or could be made out by a series of occasional monstrous conversions, and if traces could be discovered of 〈the) whole having once existed as walking or swimming instruments, these organs would be said to be metamorphosed, as it is they are only said to exhibit a common type.

This distinction is not drawn by physiologists, and is only implied by some by their general manner of writing. These facts, though affecting every organic being on the face of the globe, which has existed, or does exist, can only be viewed by the Creationist as ultimate and inexplicable facts. But this unity of type through the individuals of a group, and this metamorphosis of the same organ into other organs, adapted to diverse use, necessarily follows on the theory of descent ${ }^{2}$. For let us take case of Vertebrata, which if ${ }^{3}$ they descended from one parent and by this theory all the Vertebrata have been altered by slow degrees, such as we see in domestic animals. We know that proportions alter, and even that occasionally numbers of vertebræ alter, that parts become soldered, that parts are lost, as tail and toes, but we know (that ?) here we can see that possibly a walking organ might $\langle ?\rangle$ be converted into swimming or into a gliding organ and so on to a flying organ. But such gradual changes would not alter the unity of type in their descendants, as parts lost and soldered and vertebræ.

1 The following passage seems to have been meant to precede the sentence beginning "These faets":- "It is evident, that when in each individual speeies, organs are metamorph. a unity of type extends."

2 This is, I believe, the first place in which the anthor uses the words "theory of descent."

3 The sentenec should probably run, "Let us take the case of the rertebrata: if we assume them to be descended from one parent, then by this theory they have been altered \&e." 
But we can see that if this carried to extreme, unity lost,-Plesiosaurus. Here we have seen the same organ is formed $\langle$ ? $\rangle\langle$ for $\rangle$ different purposes $\langle$ ten words illegible): and if, in several orders of vertebrata, we could trace origin $\langle$ of $\rangle$ spinous processes and monstrosities \&c. we should say, instead of there existing a unity of type, morphology ${ }^{1}$, as we do when we trace the head as being the vertebra metamorphosed. Be it observed that Naturalists, as they use terms of affinity without attaching real meaning, here also they are obliged to use metamorphosis, without meaning that any parent of crustacean was really an animal with as many legs as crustacean has jaws. The theory of descent at once explains these wonderful facts.

Now few of the physiologists who use this language really suppose that the parent of insect with the metamorphosed jaw, was an insect with [more] so many legs, or that the parent of flowering plants, originally had no stamens, or pistils or petals, but some other means of propagation,---and so in other cases. Now according to our theory during the infinite number of changes, we might expect that an organ used for a purpose might be used for a different one by his descendant, as must have been the case by our theory with the bat, porpoise, horse, \&c., which are descended from one parent. And if it so chanced that traces of the former use and structure of the part should be retained, which is manifestly possible if not probable, then we should have the organs, on which morphology is founded and which instead of being metaphorical becomes plain and and instead of being) utterly unintelligible becomes simple matter of fact ${ }^{2}$.

1 That is "we should eall it a morphological faet."

2 In the Origin, Ed. i. p. 438, vi. p. 602, the author, referring to the expressions used by naturalists in regard to morphology and metamorphosis, says "On my view these terms may be used literally." 
〈Embryology.〉 This general unity of type in great groups of organisms (including of course these morphological cases) displays itself in a most striking manner in the stages through which the fotus passes ${ }^{1}$. In early stage, the wing of bat, hoof, hand, paddle are not to be distinguished. At a still earlier 〈stage) there is no difference between fish, bird, \&c. \&c. and mammal. It is not that they cannot be distinguished, but the arteries ${ }^{2}$ 〈illegible). It is not true that one passes through the form of a lower group, though no doubt fish more nearly related to fœtal state?

This similarity at the earliest stage is remarkably shown in the course of the arteries which become greatly altered, as fotus advances in life and assumes the widely different course and number which characterize full-grown fish and mammals. How wonderful that in egg, in water or air, or in womb of mother, artery ${ }^{4}$ should run in same course.

Light can be thrown on this by our theory. The structure of each organism is chiefly adapted to the sustension of its life, when full-grown, when it has to feed itself and propagate ${ }^{5}$. The structure of a kitten is quite in secondary degree adapted to its habits, whilst fed by its mother's milk and prey. Hence variation in the structure of the full-grown species will chiefly determine the preservation of a

1 See Origin, Ed. i. p. 439, vi. p. 605.

2 In the Origin, Ed. i. p. 440, vi. p. 606, the author argues that the "loop-like course of the arteries" in the vertebrate embryo has no direct relation to the eonditions of existence.

3 The following passages are written across the page:- "They pass through the same phases, but some, generally called the higher groups, are further metamorphosed.

? Degradation and complication? no tendency to perfection.

? Justly argued against Lamarek?"

4 An almost identical passage occurs in the Origin, Ed. i. p. 440, vi. p. 606 .

5 The following: "Deaths of brothers (when〉 old by same peculiar disease" which is written between the lines seems to have been a memorandum whieh is expanded a few lines lower. I believe the ease of the brothers came from Dr R. W. Darwin. 
species now become ill-suited to its habitat, or rather with a better place opened to it in the economy of Nature. It would not matter to the full-grown cat whether in its young state it was more or less eminently feline, so that it become so when fullgrown. No doubt most variation, (not depending on habits of life of individual) depends on early change ${ }^{1}$ and we must suspect that at whatever time of life the alteration of fotus is effected, it tends to appear at same period. When we $\langle$ see $\rangle$ a tendency to particular disease in old age transmitted by the male, we know some effect is produced during conception, on the simple cell of ovule, which will not produce its effect till half a century afterwards and that effect is not visible ${ }^{2}$. So we see in grey-hound, bull-dog, in race-horse and carthorse, which have been selected for their form in full-life, there is much less (?) difference in the few first days after birth ${ }^{3}$, than when full-grown : so in cattle, we see it clearly in cases of cattle, which differ obviously in shape and length of horns. If man were during 10,000 years to be able to select, far more diverse animals from horse or cow, I should expect there would be far less differences in the very young and foetal state: and this, I think, throws light on above marvellous fact. In larvæ, which have long life selection, perhaps, does much,-in the pupa not so much ${ }^{4}$. There is no

1 See the discussion to this effect in the Origin, Ed. i. pp. 443-4, vi. p. 610. The author there makes the distinction between a cause affecting the germ-cell and the reaction occurring at a late period of life.

2 Possibly the sentence was meant to end "is not visible till then."

3 See Origin, Ed. i. pp. 444-5, vi. p. 611 . The query appended to much less is justified, since measurement was necessary to prove that the greyhound and bulldog puppies had not nearly acquired "their full amount of proportional difference."

${ }_{4}^{4}$ 〈The following discussion, from the back of the page, is in large measure the same as the text.) I think light can be thrown on these facts. From the following peculiarities being hereditary, [we know that some change in the germinal vesicle is effected, which will only betray itself year's after] diseases -man, goitre, gout, baldness, fatness, size, [longevity 〈illegible) time of 


\section{object gained in varying form \&c. of fœtus (beyond certain adaptations to mother's womb) and there- fore selection will not further act on it, than in giving to its changing tissues a tendency to certain parts afterwards to assume certain forms. Thus there is no power to change the course of}

reproduetion, shape of horns, case of old brothers dying of same disease]. And we know that the germinal vesiele must lave been affeeted, though no effeet is apparent or ean be apparent till years afterwards, - no more apparent than when these peculiarities appear by the exposure of the fullgrown individual. (That is, "the young individual is as apparently free from the hereditary ehanges whieh will appear later, as the young is aetually free from the elranges produced by exposure to certain eonditions in adult life."> So that when we see a variety in eattle, even if the variety be due to act of reproduction, we eannot feel sure at what period this ehange became apparent. It may have been effected during carly age of free life 〈or $\rangle$ foetal existenec, as monsters show. From arguments before used, and erossing, we may generally suspeet in germ; but I repeat it does not follow, that the ehange should be apparent till life fully developed; any more than fatness depending on heredity should be apparent during early ehildhood, still less during foetal existence. In case of horns of eattle, whieh when inherited must depend on germinal vesiclc, obviously no effeet till eattle full-grown. Praetieally it would appear that the [hereditary] peeuliarities charaeterising our domestie races, therefore resulting from vesiele, do not appear with their full eharaeters in very early states; thus though two breeds of eows have calves different, they are not so different,-grey-hound and bull-dog. And this is what is $\langle$ to $\rangle$ be expeetcd, for man is indifferent to eharaeters of young animals and henee would seleet those full-grown animals whieh possessed the dcsirable eharaeteristics. So that from mere ehance we might expeet that some of the eharaeters would be such only as became fully apparent in mature life. Furthermore we may suspeet it to be a law, that at whatever time a new character appears, whether from vesiele, or effeets of external eonditions, it would appcar at corresponding time 〈see Origin, Ed. i. p. 444). Thus diseases appearing in old age produce eliildren with $\mathrm{d}^{\circ}$, - - early maturity,-longevity,-old men, brotliers, of same disease-young ehildren of $d^{0}$. I said men do not seleet for quality of young,--ealf with big bullocks. Silk-worms, peeuliarities which, appear in eaterpillar state or coeoon state, arc transmitted to eorresponding states. The effect of this would bc that if some peculiarity was born in a young animal, but never exercised, it might be inherited in young animal; but if exereised that part of strueture would be increased and would be inherited in eorresponding time of life after sueh training.

I have said that man seleets in full-life, so would it be in Nature. In struggle of existenee, it matters nothing to a feline animal, whether kitten eminently feline, as long as it sueks. Therefore natural seleetion would aet equally well on charaeter whieh was fully 〈developed〉 only in full age. Selection eould tend to alter no charaeter in foetus, (exeept relation to motlicr) it would alter less in young state (putting on one side larva eondition) but alter every part in full-grown condition. Look to a foetus and its parent, and again after ages fuetus and its (i.e. the above mentioned parents) descendant; the parcnt nore variable $\langle$ ? $\rangle$ than fotus, whiel explains all. 
the arteries, as long as they nourish the fotus; it is the selection of slight changes which supervene at any time during (illegible) of life.

The less differences of fotus,- this has obvious meaning on this view: otherwise how strange that a [monkey] horse, a man, a bat should at one time of life have arteries, running in a manner, which is only intelligibly useful in a fish! The natural system being on theory genealogical, we can at once see, why fotus, retaining traces of the ancestral form, is of the highest value in classification.

\section{§ IX. 〈ABORTIVE ORGANS.)}

There is another grand class of facts relating to what are called abortive organs. These consist of organs which the same reasoning power that shows us how beautifully these organs in some cases are adapted to certain end, declares in other cases are absolutely useless. Thus teeth in Rhinoceros ${ }^{1}$, whale, narwhal,--bone on tibia, muscles which do not move,--little bone of wing of Apteryx,--bone representing extremities in some snake,-little wings within 〈? $\rangle$ soldered cover of beetles,-men and bulls, mammæ: filaments without anthers in plants, mere scales representing petals in others, in featherhyacinth whole flower. Almost infinitely numerous. No one can reflect on these without astonishment, can anything be clearer than that wings are to fly and teeth 〈to bite〉, and yet we find these organs perfect in every detail in situations where they cannot possibly be of their normal use?

The term abortive organ has been thus applied

1 Some of these examples occur in Origin, Ed. i. pp. 450-51, vi. pp. 619-20.

2 The two following sentences are written, one down the margin, the other across the page. "Abortive organs eminently useful in classification. Embryonic state of organs. Rudiments of organs." 
to above structure (as invariable as all other parts ${ }^{1}$ ) from their absolute similarity to monstrous cases, where from accident, certain organs are not developed; as infant without arms or fingers with mere stump representing them: teeth represented by mere points of ossification: headless children with mere button,-viscera represented by small amorphous masses, \&c., - the tail by mere stump,a solid horn by minute hanging one ${ }^{2}$. There is a tendency in all these cases, when life is preserved, for such structures to become hereditary. We see it in tailless dogs and cats. In plants we see this strikingly, - in 'Thyme, in Linum flavum, - stamen in Gercuium pyrenaicum ${ }^{3}$. Nectaries abort into petals in Columbine 〈Aquilegia), produced from some accident and then become hereditary, in some cases only when propagated by buds, in other cases by seed. These cases have been produced suddenly by accident in early growth, but it is part of law of growth that when any organ is not used it tends to diminish (duck's wing ${ }^{4}$ ?) muscles of dog's ears, (and of ) rabbits, muscles wither, arteries grow up. When eye born defective, optic nerve (Tuco Tuco) is atrophied. As every part whether useful or not (diseases, double flowers) tends to be transmitted to offspring, the origin of abortive organs whether produced at the birth or slowly acquired is easily understood in domestic races of organisms: [a struggle between the atrophy and hereditariness. Abortive organs in domestic races.] There will always be a struggle between atrophy of an organ rendered useless, and

1 I imagine the meaning to be that abortive organs are specific characters in contrast to monstrosities.

2 Minute hanging horns are mentioned in the Origin, Ed. i. p. 454, vi. p. 625 , as occurring in hornless breeds of cattle.

3 Linum flavum is dimorphic: thyme gynodiæcious. It is not clear what point is referred to under Geranium pyrenaicum.

4 The author's work on duck's wings \&c. is in Var. under Dom., Ed. 2, i. p. 299. 
hereditariness ${ }^{1}$. Because we can understand the origin of abortive organs in certain cases, it would be wrong to conclude absolutely that all must have had same origin, but the strongest analogy is in favour of it. And we can by our theory, for during. infinite changes some organ, we might have anticipated, would have become useless. (We can) readily explain the fact, so astounding on any other view, namely that organs possibly useless have been formed often with the same exquisite care as when of vital importance.

Our theory, I may remark would permit an organ 〈to become abortive with respect to its primary use, to be turned to any other purpose, (as the buds in a cauliflower) thus we can see no difficulty in bones of male marsupials being used as fulcrum of muscles, or style of marygold ${ }^{2}$,-indeed in one point of view, the heads of [vertebrated] animal may be said to be abortive vertebra turned into other use: legs of some crustacea abortive jaws, \& c., \&c. De Candolle's analogy of table covered with dishes ${ }^{3}$.

(The following passage was possibly intended to be inserted here.) Degradation and complication see Lamarck: no tendency to perfection: if room, [even] high organism would have greater power in beating lower one, thought $\langle ?\rangle$ to be selected for a degraded end.

1 The words vis medicatrix are inserted after "useless," apparently as a memorandum.

${ }^{2}$ In the male florets of certain Compositxe the style functions merely as a piston for forcing out the pollen.

3 (On the back of the page is the following.) If abortive organs are a trace preserved by hereditary tendency, of organ in ancestor of use, we can at once see why important in natural classification, also why more plain in young animal because, as in last section, the selection has altered the old animal most. I repeat, these wondrous facts, of parts created for 110 use in past and present time, all can by ny theory receive simple explanation; or they receive none and we must be content with some such empty metaphor, as that of De Candolle, who compares creation to a well covered table, and says abortive organs may be compared to the dishes (some should be empty) placed symmetrically ! 


\section{$\S$ x. Recapitulation and conclusion.}

Let us recapitulate the whole $\langle ?\rangle\langle$ of $\rangle$ these latter sections by taking case of the three species of Rhinoceros, which inhabit Java, Sumatra, and mainland of Malacca or India. We find these three close neighbours, occupants of distinct but neighbouring districts, as a group having a different aspect from the Rhinoceros of Africa, though some of these latter inhabit very similar countries, but others most diverse stations. We find them intimately related [scarcely $\langle ?\rangle$ differences more than some breeds of cattle] in structure to the Rhinoceros, which for immense periods have inhabited this one, out of three main zoological divisions of the world. Yet some of these ancient animals were fitted to very different stations: we find all three 〈illegible〉 of the generic character of the Rhinoceros, which form a [piece of net] ${ }^{1}$ set of links in the broken chain representing the Pachydermata, as the chain likewise forms a portion in other and longer chains. We see this wonderfully in dissecting the coarse leg of all three and finding nearly the same bones as in bat's wings or man's hand, but we see the clear mark in solid tibia of the fusion into it of the fibula. In all three we find their heads composed of three altered vertebræ, short neck, same bones as giraffe. In the upper jaws of all three we find small teeth like rabbit's. In dissecting them in fœtal state we find at a not very early stage their form exactly alike the most different animals, and even with arteries running as in a fish: and this similarity holds when the young one is produced in womb, pond, egg or spawn. Now these three undoubted species scarcely differ more than breeds of cattle,

1 The author doubtless meant that the complex relationships between organisms can be roughly represented by a net in which the knots stand for species. 
are probably subject to many the same contagious diseases; if domesticated these forms would vary, and they might possibly breed together, and fuse into something ${ }^{1}$ different (from) their aboriginal forms; might be selected to serve different ends.

Now the Creationist believes these three Rhinoceroses were created $^{2}$ with their deceptive appearance of true, not (illegible) relationship; as well can I believe the planets revolve in their present courses not from one law of gravity but from distinct volition of Creator.

If real species, sterile one with another, differently adapted, now inhabiting different countries, with different structures and instincts, are admitted to have common descent, we can only legitimately stop where our facts stop. Look how far in some case a chain of species will lead us. /This probably refers to the Crustacea, where the two ends of the series have "hardly a character in common." Origin, Ed. i. p. 419.) May we not jump (considering how much extermination, and how imperfect geological records) from one sub-genus to another sub-genus. Can genera restrain us; many of the same arguments, which made us give up species, inexorably demand genera and families and orders to fall, and classes tottering. We ought to stop only when clear unity of type, independent of use and adaptation, ceases.

$B e$ it remembered no naturalist pretends to give test from external characters of species ; in many genera the distinction is quite arbitrary ${ }^{3}$. But there remains one other way of comparing species

1 Between the lines occurs :- "one $\langle ?\rangle$ form be lost."

2 The original sentence is here broken up by the insertion of :- "out of the dust of Java, Sumatra, these $\langle ?\rangle$ allied to past and present age and 〈illegible), with the stamp of inutility in some of their organs and conversion in others."

${ }^{3}$ Between the lines occur the words :- "Species vary according to same general laws as varieties ; they cross according to same laws."

D. 
with races; it is to compare the effects of crossing them. Would it not be wonderful, if the union of two organisms, produced by two separate acts of Creation, blended their characters together when crossed according to the same rules, as two races which have undoubtedly descended from same parent stock; yet this can be shown to be the case. For sterility, though a usual (?), is not an invariable concomitant, it varies much in degree and has been shown to be probably dependent on causes closely analogous with those which make domesticated organisms sterile. Independent of sterility there is no difference between mongrels and hybrids, as can be shown in a long series of facts. It is strikingly seen in cases of instincts, when the minds of the two species or races become blended together ${ }^{1}$. In both cases if the half-breed be crossed with either parent for a few generations, all traces of the one parent form is lost (as Kölreuter in two tobacco species almost sterile together), so that the Creationist in the case of a species, must believe that one act of creation is absorbed into another!

\section{Concludion.}

Such are my reasons for believing that specific forms are not immutable. The affinity of different groups, the unity of types of structure, the representative forms through which fœtus passes, the metamorphosis of organs, the abortion of others cease to be metaphorical expressions and become intelligible facts. We no longer look $\langle a n\rangle$ on animal as a savage does at a ship ${ }^{2}$, or other great work of art, as a thing wholly beyond comprehension, but we

1 "A cross with a bull-dog has affected for many generations the courage and obstinacy of greyhounds," Origin, Ed. i. p. 214, vi. p. 327.

2 The simile of the savage and the ship occurs in the Origin, Ed. i. p. 485 , vi. p. 665 . 


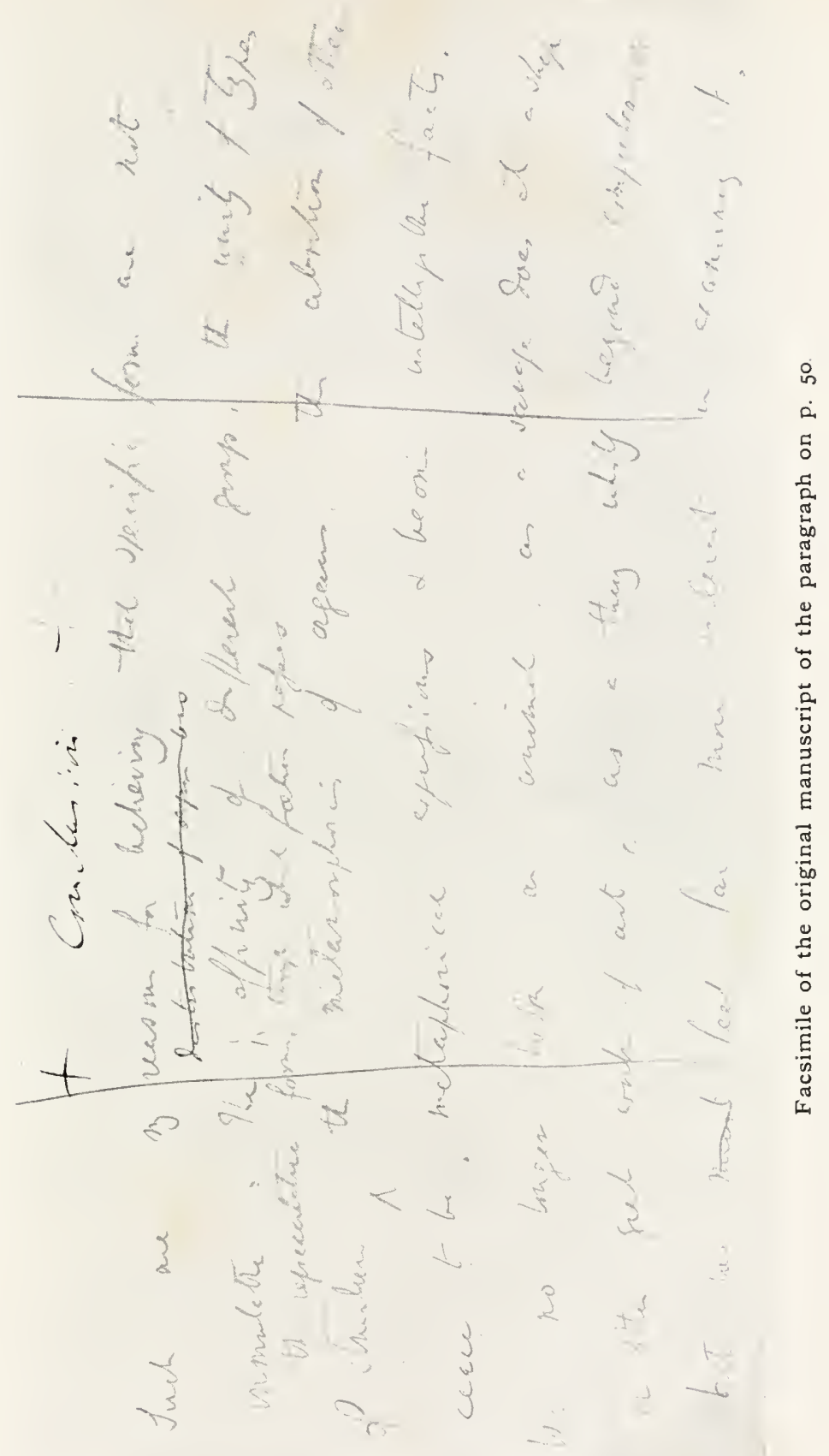



feel far more interest in examining it. How interesting is every instinct, when we speculate on their origin as an hereditary or congenital habit or produced by the selection of individuals differing slightly from their parents. We must look at every complicated mechanism and instinct, as the summary of a long history, (as the summing up) of ${ }^{1}$ useful contrivances, much like a work of art. How interesting does the distribution of all animals become, as throwing light on ancient geography. [We see some seas bridged over.] Geology loses in its glory from the imperfection of its archives ${ }^{2}$, but how does it gain in the immensity of the periods of its formations and of the gaps separating these formations. There is much grandeur in looking at the existing animals either as the lineal descendants of the forms buried under thousand feet of matter, or as the coheirs of some still more ancient ancestor. It accords with what we know of the law impressed on matter by the Creator, that the creation and extinction of forms, like the birth and death of individuals should be the effect of secondary [laws] means $^{3}$. It is derogatory that the Creator of countless systems of worlds should have created each of the myriads of creeping parasites and [slimy] worms which have swarmed each day of life on land and water 〈on〉 [this] one globe. We cease being astonished, however much we may deplore, that a group of animals should have been directly created to lay their eggs in bowels and flesh of other,- that some organisms should delight in cruelty,- that animals should be led away by false instincts,- that annually there should be an

1 In the Origin, Ed. i. p. 486 , vi. p. 665, the author speaks of the "summing up of many contrivances": I have therefore introduced the above words which make the passage clearer. In the Origin the comparison is with "a great mechanical invention,"-not with a work of art.

2 See a similar passage in the Origin, Ed. i. p. 487 , vi. p. 667.

3 See the Origin, Ed. i. p. 488 , vi. p. 668. 
incalculable waste of eggs and pollen. From death, famine, rapine, and the concealed war of nature we can see that the highest good, which we can conceive, the creation of the higher animals has directly come. Doubtless it at first transcends our humble powers, to conceive laws capable of creating individual organisms, each characterised by the most exquisite workmanship and widely-extended adaptations. It accords better with [our modesty] the lowness of our faculties to suppose each must require the fiat of a creator, but in the same proportion the existence of such laws should exalt our notion of the power of the omniscient Creator ${ }^{1}$. There is a simple grandeur in the view of life with its powers of growth, assimilation and reproduction, being originally breathed into matter under one or a few forms, and that whilst this our planet has gone circling on according to fixed laws, and land and water, in a cycle of change, have gone on replacing each other, that from so simple an origin, through the process of gradual selection of infinitesimal changes, endless forms most beautiful and most wonderful have been evolved ${ }^{2}$.

1 The following diseussion, together with some memoranda are on the last page of the MS. "The supposed ereative spirit does not ereate either number or kind which 〈are from analogy adapted to site (viz. New Zealand): it does not keep them all permanently adapted to any eonntry,-it works on spots or areas of ereation,-it is not persistent for great periods,-it ereates forms of same groups in same regions, with no physieal similarity,-it ereates, on islands or mountain summits, speeies allied to the neighbouring ones, and not allied to alpine nature as shown in other mountain summits - even different on different island of similarly eonstitnted arehipelago, not ereated on two points : never mammifers ereated on small isolated island; nor nmmber of organisms adapted to loeality : its power seems influeneed or related to the range of other speeies wholly distinet of the same genus, -it does not equally effect, in amount of differenee, all the groups of the same elass."

${ }_{2}^{2}$ This passage is the aneestor of the eoneluding words in the first edition of the Origin of Species which have remained substantially unchanged throughout subsequent editions, "There is grandeur in this view of life, with its several powers, having been originally breathed into a few forms or into one; and that whilst this planet has gone eyeling on aceording to the fixed law of gravity, from so simple a beginning endless forms most 
N.B.-There ought somewhere to be a discussion from Lyell to show that external conditions do vary, or a note to Lyell's works (work ?).

Besides other difficulties in ii. Part, non-acclimatisation of plants. Difficulty when asked how did white and negro become altered from conmon intermediate stock: no facts. We do Nот know that species are immutable, on the contrary. What arguments against this theory, except our not perceiving every step, like the erosion of valleys ${ }^{1}$.

beautiful and most wonderful have been, and are being, evolved." In the 2nd edition "by the Creator" is introdueed after "originally breathed."

1 Compare the Origin, Ed. i. p. 481, vi. p. 659, "The diffieulty is the same as that felt by so many geologists, when Lyell first insisted that long lines of inland eliffs had been formed, and great valleys exeavated, by the slow aetion of the eoast-waves." 





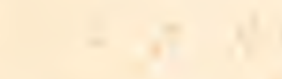




\section{$4 x^{2}=8$}

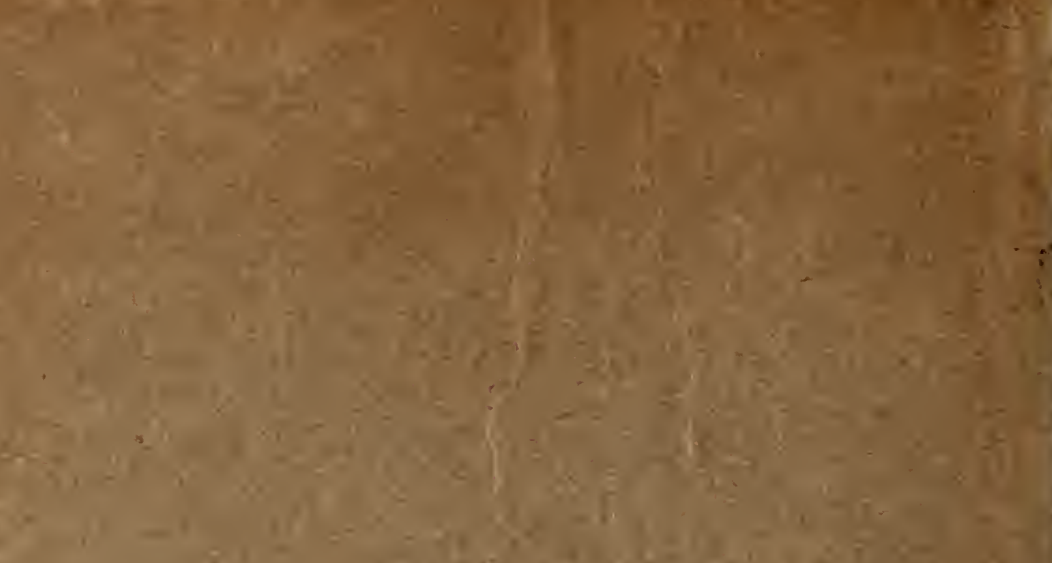

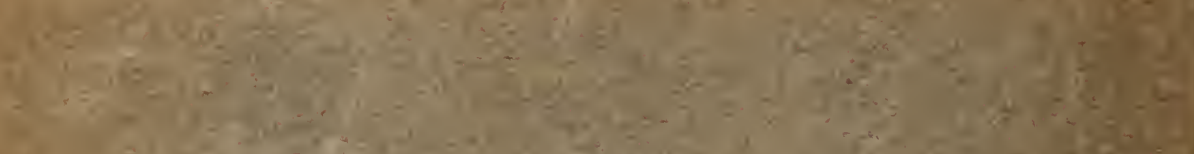

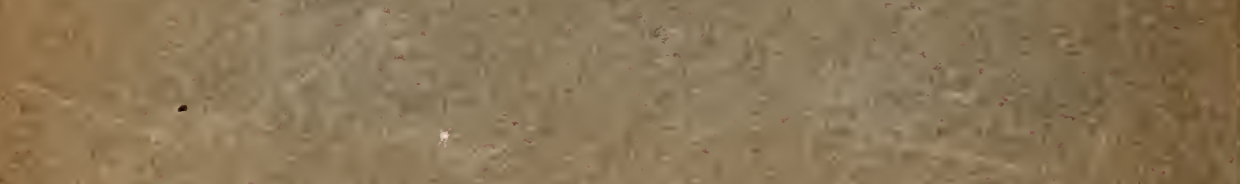

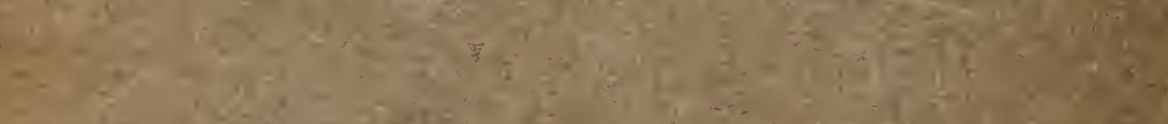

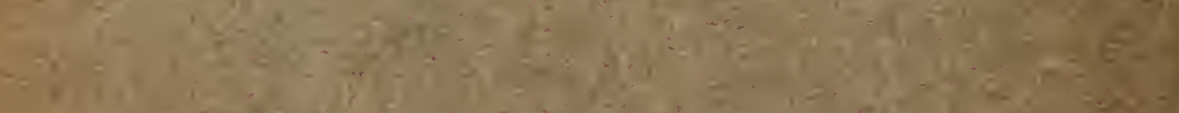

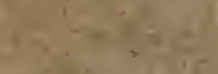
; 